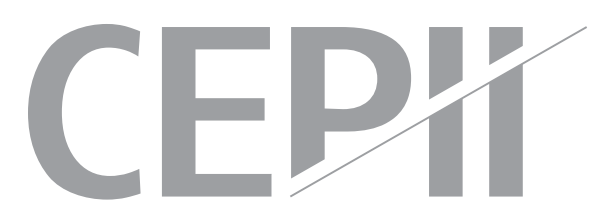

\title{
Shooting Oneself in the Foot? Trade War and Global Value Chains
}

Cecilia Bellora \& Lionel Fontagné

\section{Highlights}

- By entering into a trade war, the US administration reached its goal to weaken the Chinese economy and protect certain industries, but this comes at a cost for the US economy itself, because GVCs are ubiquitous in most of the protected sectors.

- The increase in producer costs, caused by increased tariffs on goods for intermediate consumption, is detrimental to the competitiveness of US producers. This translates into losses of US market shares on export markets, adding to the toll of retaliation by China and other affected countries. Overall, US exports to the world post a sizeable decrease.

- Because of the tariffs in place as of February 2020, in our General Equilibrium setup, three quarters of the sectors decrease their value added in the US.

- Consistent with political economy determinants, these twists of value added are transmitted to production factors, leading to sizeable creation and destruction of jobs, and reallocation of capital to the benefit of protected sectors, mostly at the expense of their clients, i.e. downstream industries. 


\section{Abstract}

Despite the "Phase One Deal" agreed on mid-December 2019, bilateral tariffs between US and China remain at unprecedented high levels, which will have long-lasting effects. US tariffs remain very high on parts, components and other intermediate products; similarly, only the last wave of Chinese retaliatory tariffs has been half cut. We investigate in this paper how such tensions between highly interdependent economies will impact trade, income and jobs. We rely on a set-up featuring General Equilibrium, imperfect competition and importantly differentiating demand of goods according to their use, for final or intermediate consumption. This authorizes tracing the impact of protection along the value chains, on prices, value added and factor income. Additional tariffs from official lists are taken into account at the tariff line level, before being aggregated within sectors. Beyond the direct toll of sanctions, US exports to the world post a sizeable decrease as a result of reduced competitiveness led by vertical linkages along the value chains. Because of the tariffs in place as of February 2020, three quarters of the sectors decrease their value added in the US. Consistent with political economy determinants, these twists of value added are transmitted to production factors, leading to sizeable creation and destruction of jobs, and reallocation of capital to the benefit of protected sectors, mostly at the expense of their clients. Ultimately, this paper sheds light on the economic consequences of policies disrupting global value chains.

\section{Keywords}

Trade War, Global Value Chains.

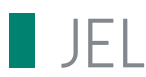

F13, F17.

\section{Working Paper}

CEPII (Centre d'Etudes Prospectives et
d'Informations Internationales) is a French institute
dedicated to producing independent, policy-
oriented economic research helpful to understand
the international economic environment
and challenges in the areas of trade policy,
competitiveness, macroeconomics, international
finance and growth.

CEPII Working Paper

Contributing to research in international economics

(c) CEPII, PARIS, 2020

All rights reserved. Opinions expressed in this publication are those of the author(s) alone.

$\begin{array}{ll}\text { Editorial Director: } & \text { CEPII } \\ \text { Sébastien Jean } & \text { 20, avenue de Ségur } \\ & \text { TSA 10726 } \\ \text { Production: Laure Boivin } & \text { 75334 Paris Cedex 07 } \\ \text { Published on 16.04.20 } & +33153685500 \\ \text { No ISSN: 1293-2574 } & \text { www.cepii.fr } \\ & \text { Press contact: presse@ }\end{array}$




\title{
Shooting Oneself in the Foot? Trade War and Global Value Chains ${ }^{1}$
}

\author{
Cecilia Bellora* and Lionel Fontagné ${ }^{\dagger}$
}

\section{Introduction}

The "Phase One Deal" agreed on mid-December 2019 did not reduce the additional tariffs implemented since the beginning of 2018 but established a new normal consisting in sizeable trade frictions. These frictions between highly interdependent economies will have long lasting effects. China committed to kind of "managed trade" consisting in an extra USD 200 billion imports from the US by the end of 2021 - a target that will hardly be reached as a consequence of the sanitary crisis - and to avoid resorting to competitive devaluations. What the phase one provides is accordingly a pause in the escalation, with US additional tariffs expected in December 2019 cancelled as well as the induced Chinese retaliatory tariffs. ${ }^{2}$ The last US tariffs, set at 15\% on USD 100 bn USD imports of Chinese goods have been halved, but the $25 \%$ tariffs on 250 bn USD Chinese exports have been maintained. Interestingly, the confirmed US tariffs are concentrated on parts, components and other intermediate products and the deal enshrines high bilateral tariffs as a new normal. For sure, managed trade would Chinese commitments be effective - is better than a further escalation, but it will leave everyone worse off (but the US and Mexico) due to trade diversion (Freund, Maliszewska, Matoo and Ruta, 2020).

We focus on this episode of trade war and examine the consequences on trade, sectoral value added, jobs and welfare of this durable return to protectionism. This quasi-natural experiment has initiated in-depth economic analysis of the effects on trade and welfare for the US economy (Amiti, Redding and Weinstein, 2019a, 2020, Fajgelbaum, Goldberg, Kennedy and Khandelwal, 2020); on the pass-through of tariffs into prices (Cavallo, Gopinath, Neiman and Tang, 2019); and on consumption at the county level (Waugh, 2019).

Interestingly, this return to protectionism is taking place in a world economy characterized by Global Value Chains (GVCs). Fragmented production should discourage tariffs on imports of final goods embarking previously exported domestic value added, and on imports of intermediate goods entering into the domestic production process (Koopman, Tsigas, Riker and Powers, 2013, Blanchard, Bown and Johnson, 2016, Bown, Erbahar and Zanardi, 2020). ${ }^{3}$ Is it how US and China proceeded, or did the two countries engage in a tariff escalation

\footnotetext{
${ }^{1}$ Originally published in December 2019, updated on April 16, 2020.

*CEPII, (cecilia.bellora@cepii.fr)

${ }^{\dagger}$ Paris School of Economics - Université Paris I and CEPII, (lionel.fontagne@univ-paris1.fr)

${ }^{2}$ There is no commitment to reduce Chinese tariffs in the Phase One Deal, although China started reducing its retaliatory tariffs. By the end of December 2019, China exempted 660 million USD exports of chemical products from announced retaliatory tariffs, while retaliatory tariffs imposed on US exports in September 2019 were cut in half in February 2020.

'Using an augmented political economy model of trade policy, Blanchard et al. (2016) show that GVC linkages modify countries' incentives to impose import protection. Tariffs should be decreasing in the domestic content of foreign-produced final goods and
} 
detrimental to their own value added and hence factor income? ${ }^{4}$ To answer these questions requires combining the most detailed information on protection measures (in order to spot the final versus intermediate use of imports) with a consistent modeling of trade and value added, both at the sectoral and global levels.

The new tariffs have indeed a direct impact on the targeted products and countries, but GVCs, along with General Equilibrium effects, trigger additional consequences worth investigating. From the US perspective, exports of final and intermediate goods are directly affected by Chinese retaliation. But US exports also suffer a loss of competitiveness on all markets (including the domestic one), as production costs increase in industries using taxed imported goods as inputs. Using micro level data, Handley, Kamal and Monarch (2019) show that the induced drop in US exports is equivalent to a $2 \%$ tariff imposed on US exports. By the same token, restricting Chinese exports to the US market that contain previously exported US intermediate inputs also hurts the US value added. We should expect from these mechanisms an overall negative impact of US tariffs on US value added in numerous sectors, either directly or indirectly. And since value added is split among production factors, such as skilled and unskilled labor, capital or land owners, the final outcome of this trade war has indeed resonance in terms of political economy. These are the effects that will be tackled in this paper.

As said, we are not the first to look at the impacts of the measures introduced since 2018 or, more generally, of a broader trade war. Amiti et al. (2019a) address the impact of the US-China trade war on prices and welfare, taking stock of the disruption of GVCs. As opposed to most of the exercises in the literature, they use detailed (at the 10-digit level of the US Harmonized Tariff Schedule) information on unit values (tariff-inclusive "prices") at the US border. Most of the cost of the war is shown to fall on US consumers due to almost full pass-trough of the tariffs by foreign exporters and reduced competition on the US market. The magnitude of the price effect in the US is estimated to be one percentage point. Fajgelbaum et al. (2020) also rely on detailed trade data and compute trade elasticities used in supply-side model of the US economy. ${ }^{5}$

Structural gravity and new quantitative trade models have also been mobilized to assess the consequences of a trade war. Berthou, Jardet, Siena and Szczerbowicz (2018) and Vicard (2018) focus more on a stylized trade war scenario inspired from Ossa (2014) or Nicita, Olarreaga and Silva (2018) and provide impacts by country but not by sector. Felbermayr and Steininger (2019) rely on an input-output gravity approach à la Caliendo and Parro (2015) to assess the static economic impact of the trade war between the US and China on the two countries and on the EU as well. They show that China loses but the US as well, while the impact of this bilateral trade war is slightly favourable to Europe. However, their exercise neither takes into account US

in the imported content of domestic production of final goods. Using data on temporary protection for 14 major traders over the period 1995-2009 they confirm that the importance of GVCs is curbing the use of protection, especially against China. Bown et al. (2020) show a causal effect of GVC integration (bilateral industry-specific domestic value-added growth) on the removal of duties over 1995-2013.

${ }^{4}$ Bown (2018) provides evidence that, even before the recent escalation, temporary trade barriers have moved away from final goods towards intermediate goods, starting from 2010, following a pattern contrary to the ubiquitous tariff escalation.

${ }^{5}$ International organizations also performed impact assessments in general equilibrium, e.g. Caceres, Cerdeiro and Mano (2019), Bekkers and Teh (2019). 
tariffs on EU and subsequent European retaliations, nor the specific treatment of the countries that negotiated Voluntary Exports Restraints (VERs) in the US in the Steel and Aluminum case (e.g. Korea).

A last strand of literature is relying on Computable General Equilibrium modelling. Freund, Ferrantino, Maliszewska and Ruta (2018) propose an impact assessment of the first round of tariff increases between the US and China under the Section 301. Balistreri, Böhringer and Rutherford (2018) use the most detailed available information on the measures, i.e. the official tariff lists, compounded by Li, Balistreri, Zhang et al. (2018), in their simulations. They assess their impacts using three alternative model structures and focus their presentation on US sectoral output. Li et al. (2018) produce simulations of the very detailed tariff scenario, but they do not take into account the VERs and adopt a simple canonical model. Charbonneau and Landry (2018) also use a complete and detailed tariff scenario to assess the impact on trade and value added but they consider separately the different waves of tariffs, disregarding their non-linear effects. ${ }^{6}$

We add to the literature by relying on information at the most detailed level on sanctions and retaliations, and by encapsulating this information in a General Equilibrium framework featuring imperfect competition and GVCs. As for tariff increases, we rely on the official lists, but our scenarios differ from the recent literature (i) in the way we aggregate these information and (ii) in how we take into account VERs. Importantly, beyond trade effects (here distinguishing between intermediate and final goods), we track impacts of the trade war on prices, value added, and factor incomes, stressing their heterogeneity across sectors and countries. Our results suggest that, in the long run, because of the tariffs in place as of February 2020, China and the United States could experience GDP losses by $0.59 \%$ and $0.41 \%$ respectively. ${ }^{7}$ Beyond such aggregated effects, as a result of vertical linkages along the value chains, we show that 20 out of 26 US sectors ${ }^{8}$ decrease their value added.

In terms of tariff escalation, the final outcome of the trade war is a moving target. In March 2018, the US imposed additional tariffs of $10 \%$ and $25 \%$ on their imports of aluminium and steel, respectively. Exceptions to these tariffs were only a few and took the form of exemption or negotiated VERs. As a result, several countries retaliated increasing their own tariffs on targeted US products. From May 2018 onwards, new US trade restrictions mainly targeted China, with an unprecedented intensity. The reason invoked this time is the retaliation against unfair Chinese trade practices on technology transfers and intellectual property. Additional tariffs entered into force in different waves: US imports from China worth USD 50 bn were affected between June and July 2018, further USD 200 bn in September 2018. In the first months of 2019, tensions seemed to be contained; the two opponents tried to negotiate a truce, but without success, at least in the first instance. As a result, additional taxes already imposed on 200 bn Chinese exports moved from 10 to 25 p.p. in May

\footnotetext{
${ }^{6}$ Koopman et al. (2013) also investigate the implications of GVCs for trade policy, embarking (or not) information on the usage of products.

${ }^{7}$ Amiti, Redding and Weinstein $(2019 \mathrm{~b})$ show that the impact of tariffs on US imports is increasing over time, confirming that reorganizing global value chains takes time. We focus here on long term impacts accounting for such firms' adjustments to trade tensions.

${ }^{8}$ We actually rely on a 27-sector aggregation but there is no US value added in the Oil sector (corresponding to the extraction of crude petroleum) in our database, its base year being 2011.
} 
2019. China retaliated against each of these waves, responding with $5 \%$ to $25 \%$ additional tariffs. By early June 2019, additional tariffs affected more than $51 \%$ of the goods imported by the US from China, in value, while Chinese retorsions applied on more than $72 \%$ of imports from the US. China and the US finally reached a "Phase One Deal", announced in December 2019, but only after a last wave of additional tariffs took effect in September 2019. Even if it avoids the last wave of tariff initially expected by mid-December and halves the tariffs applied in September 2019, the deal freezes the rest of protection on US imports from China at unprecedented levels. Accordingly, we provide an up to date assessment of the economic consequences of the tariffs in force by mid February 2020, on the mechanisms at stake in presence of highly interdependent economies, and on two stylized potential exits (sanctions on cars versus phasing out of remaining industrial tariffs in transatlantic commercial relationships). ${ }^{9}$

The remaining of the paper is organized as follows. In section 1 , we present the model and data. We then develop two sets of scenarios in Section 2: our central scenario presents the measures in force as of February 2020 and analyze their long term impacts, while two additional scenarios rather explore alternative routes, namely a further trade liberalization between the US and the European Union and on the opposite, a further escalation, in particular on the automobile sector. Beyond trade impacts, our focus is on the impact of this shift to protectionism on value added, prices, factor income and factor reallocation across sectors. We then discuss the political economy of the trade war from the US point of view in section 3. The last section concludes.

\section{Empirical strategy}

Modeling in General Equilibrium is a good candidate to address the effects of a trade war, in particular when the dynamic impacts of the conflict have to be characterized and when changes in prices have to be tracked along the value chains. Sectors adjust their intermediate consumption basket to tariff-induced price changes, labor force and capital accumulate, and the overall setting can be linked to a macroeconomic baseline. We rely here on the model MIRAGE-e that differentiates demand of goods according to their use, for final or intermediate consumption, thus explicitly representing GVCs. Therefore, our approach combines three tools: (i) a global and sectoral model featuring imperfect competition and recursive dynamics; (ii) a database of applied tariffs that can be shocked at the HS6-digit level by aggregating measures enforced at the tariff line level; and (iii) a dynamic baseline of the world economy up to 2030. We present sequentially these three elements.

\footnotetext{
${ }^{9}$ Other changes in US protection or Chinese retaliatory policies are disregarded in our exercise: a series of tariffs targeting USD 11 bn EU exports had been announced on April 8th 2019, and finally implemented based on the results of the WTO arbitration on aircrafts, while a series of tariffs is expected during the Spring 2020 after the arbitration of another file of the Airbus-Boeing dispute. The commitments taken in the "Phase one" deal on import volumes are not taken into account either.
} 


\subsection{The General Equilibrium model}

MIRAGE-e is the multi-sector and multi-region computable general equilibrium model developed at the CEPII to assess the impact of trade policies and the interactions between trade and climate change. We rely on version 2 of MIRAGE-e which innovates by featuring GVCs. ${ }^{10}$

In MIRAGE-e, firms interact either in a monopolistic competition (a number of identical firms in each sector and region compete one with another and charge a markup over marginal costs) or in a perfect competition framework (a representative firm by sector and region charges the marginal cost). Production combines valueadded plus energy and intermediate consumption, while demanding five primary factors (labor with two different skill levels, capital, land, natural resources), fully employed.

In each region, a representative consumer gathers households and the government. It maximizes its utility under its budget constraint. This representative agent saves a part of her income and spends the rest on commodities, according to a LES-CES functional form.

Trade is represented with two different Armington structures, one for final consumption and one for trade in intermediates. This double structure explicitly accounts for GVCs. ${ }^{11}$ What the double Armington structure indeed captures is the difference in the preferences in the base year for a given sector (e.g. Vehicles) since, for instance, the share of imports coming from a given country is not the same whether they are of final (e.g. cars) or intermediate goods (e.g. components). Furthermore, it allows to apply policy shocks differentiated by the use of goods. Trade can be impacted by a wide range of measures, systematically differentiated according to the use of the affected goods. We explicitly consider tariffs and export taxes. Trade restrictiveness of non-tariff measures (NTMs), both on goods and on services, is also taken into account, under three possible different forms: tariff equivalents, export tax equivalents and iceberg costs. Section 1.2 provides details on data sources for each of this measures. International transportation is explicitly modelled: transportation demand is ad volumen, it can be satisfied through different transport modes, supplied by different countries.

Finally, MIRAGE-e is a recursive dynamic model: agents optimize their choices intra-temporally and the model is solved each year until the last year considered in the simulation. A putty-clay formulation captures the rigidity in capital reallocation across periods: the stock of capital is immobile, while investments are allocated each year across sectors according to relative return rates. In other words, structural adjustments result from the inertial reallocation of the stock of capital via depreciation and investment. The baseline required for dynamic simulations is calibrated in close relationship with the MaGE model and the resulting EconMap database (Fouré,

\footnotetext{
${ }^{10}$ Version 1 of the model is documented in Fontagné, Fouré and Ramos (2013). More information on the version used here is available on the MIRAGE wiki: https://wiki.mirage-model.eu. MIRAGE stands for Modelling International Relationships in Applied General Equilibrium. The code of the model is accessible in a dedicated Git repository.

${ }^{11}$ Elasticities of substitution across origins do not differ according to the use of goods, meaning that we actually assume that the behavior of an importer is the same whatever the kind of good (for final or intermediate use). These elasticities were estimated by Hertel, Hummels, Ivanic and Keeney (2007).
} 
Bénassy-Quéré and Fontagné, 2013) to deal with world structural change at medium-run horizon (2030).

The model is calibrated using the ImpactECON database (Walmsley and Minor, 2016) featuring a decomposition of trade in goods and services by final or intermediate use that is consistent with GTAP $9 .{ }^{12}$ This release of the GTAP database features 2011 as the last reference year. The geographic decomposition is 140 regions of the world economy for 57 sectors. We aggregate this data into 27 sectors and 21 regions or countries (see Appendix $\mathrm{D}$ for the detailed aggregation).

We shock the model in 2018 and examine the deviation from the baseline at each date till 2030, for the variables of interest (trade, sectoral value added, prices, factor income, etc.). The two series of events we take on board are the so-called "Section 232" (of the Trade Expansion Act of 1962) on US imports of aluminium and steel (including exemptions, quotas and retaliation) and the "Section 301" (of the Trade Act of 1974) applied to US imports from China in several waves. ${ }^{13}$ We do take into account tariffs present by February 14, 2020, This means that, we do model the lists 1 to $4 \mathrm{~A}$ of Section 301, as defined by the US Trade Representative, ${ }^{14}$ including the halving of additional tariffs imposed on the list 4A (and the related Chinese retaliation) that occurred in February 2020, the day in which the US-China deal entered into force. ${ }^{15}$

\subsection{Protection data}

Market Access Map (MAcMap) provides a disaggregated, exhaustive and bilateral measurement of applied tariff duties at the product or tariff line level. It takes regional agreements and trade preferences exhaustively into account. The raw source data is from ITC (UNCTAD-WTO). The HS6 data set used here was constructed by the CEPII (Guimbard, Jean, Mimouni and Pichot, 2012) for analytical purposes and provides an ad valorem equivalent (percentage) of applied protection for each triplet importer-exporter-product. To minimize endogeneity problems (when computing unit values or when aggregating data), it relies on "reference groups" of countries: bilateral unit values and bilateral trade are replaced by those of the reference group of countries in the weighting scheme (Bouet, Decreux, Fontagné, Jean and Laborde, 2008). MAcMap-HS6 treats specific duties

\footnotetext{
12The "ImpactECON Global Supply Chain package" allows converting the GTAP 9.0 data into a global supply chain database. Since the goods traded in GTAP are aggregated within sectors over numerous HS-6 products categories, a given resulting sector can provide the same category of good to final consumer and to other sectors that use it as an intermediate product. Tariffs differ by HS6 category and thus by main use of the output of the sectors, as well as by the source and destination of the good. Combining COMTRADE and the Broad Economic Categories of the UN, ImpactECON fixes this problem: each bilateral flow in a GTAP sector is split into final and intermediate use. The GTAP 9.0 database is thus converted into a "Global Supply Chain Database", a database of value of imports of commodities purchased by sectors (intermediate), households (final), government and investment (final), by source and destination country/region, at market, agent and world prices. Notice that although the database also provides the tariffs aggregated along the same dimensions, we do not rely on the latter as we proceed with our own aggregation of the MAcMap HS6 database.

${ }^{13}$ We do not consider more minor sanctions imposed by the US on solar panels and washing machines in January 2018 , which resulted from a petition filled by US industries under Section 301. The Chinese government temporarily retaliated on sorghum in April of the same year.

${ }^{14}$ https://ustr.gov/issue-areas/enforcement/section-301-investigations/tariff-actions

${ }^{15}$ In 2018, China imposed retaliatory tariffs on autos and parts imported from the US. It then suspended them on January 2019 , but announced on August 2019 that the suspension would end on December 15, 2019. On December 13, 2019, in the latest twist, China decided to suspend the return into force of tariffs on autos, as a sign of good will in the context of the upcoming signature of "Phase One Deal". As a consequence, notwithstanding this uncertainty, our scenarios do not include additional tariffs imposed by China on its imports of autos and parts from the US.
} 
(per unit) as well as TRQs and offers MFN for all WTO members. The last two years reported in MAcMap are 2011 and 2013, both considered in the following exercise. Ad valorem equivalents of NTMs affecting goods are taken from Kee, Nicita and Olarreaga (2008), they are split across import taxes, export taxes and iceberg costs in an equally proportional way. Ad valorem equivalents of NTMs applying to services are from Fontagné, Mitaritonna and Signoret (2016) and are taken into account in the form of iceberg trade costs.

An important part of the work is to recollect the exact information on trade sanctions and retaliation, using original sources. We are not the first to do this, but our recollection differs slightly from tariff lists used in other papers, possibly because we used the updated versions of these lists (we rely on official lists of products as in February 2020, as defined in the Federal register and on the web sites of the imposing administrations, taking into account the changes in the list of products, see Appendix B). ${ }^{16}$

How are the tariff shocks implemented? When additional tariffs are determined at the 8- or 10-digit level of the nomenclature, we take the simple mean over all the products within the entire HS6 line to compute an additional tariff for the HS6 line. This additional tariff is then applied to the tariff reported in the MAcMap database. The aggregation at the level of the sectors considered in the simulations is done using a reference group weighted average (Bouet et al., 2008), as detailed previously. We make here the assumption of a full pass through of tariffs into prices, as suggested by the recent literature (Amiti et al., 2019a). The shocks identified at the tariff line level are added to the baseline protection, at the sectoral level of MIRAGE-e. Some trading partners of the US have negotiated TRQs instead of tariffs. We model them as VERs, assuming that quotas are filled. Therefore, we constrain quantities exported in the simulations, the targeted quantity being reached using an endogenous export tax. This way the rent of the TRQ is actually captured by the exporter, as it is the case for VERs.

\subsection{The dynamic baseline}

The effects of the trade war are measured in terms of deviation from a dynamic baseline, using a ten years horizon in order to fully capture the dynamic adjustments of the economies. The baseline is build in two steps. First, it relies on a macroeconomic model of the world economy, used in projection up to 2030 (Fouré et al., 2013. Appendix A provides details on the macroeconomic model). For each country, the GDP, the savings rate, the current account, and the energy efficiency are consistently projected. They are then used as an exogenous trajectory of MIRAGE-e, the consistency of the assumptions between the two models being ensured by endogenizing the Total Factor Productivity. This is the first step of the construction of our baseline.

In a second step, we update the tariff protection to its level of 2013 (the most recent available in the MAcMap-

\footnotetext{
${ }^{16}$ In particular, the lists used here are different from those proposed by the China Ag Center of the CARD, Iowa State University (Li, 2018). See https://www.card.iastate.edu/china/trade-war-data/.
} 
HS6 database $)^{17}$ and represent - in a stylized way - the most recently signed or negotiated trade agreements: the Comprehensive and Progressive Agreement for Trans-Pacific Partnership (CPTPP), the EU-Japan Economic Partnership Agreement, the Comprehensive Economic and Trade Agreement between the EU and Canada and a soft Brexit. ${ }^{18}$ For all the new trade agreements, we remove all the tariffs but leave the NTMs unchanged.

To sum up, the general equilibrium model is first run to calibrate the TFPs; a second run, updating trade protection, then constitutes what we consider our baseline. We then build policy scenarios, in which we implement the trade policies we are interested in. The only element that differs between the baseline and a policy scenario is the policy of interest. Then, comparing the economic outcomes of the policy scenario to those of the baseline allows to assess the impact of the trade policy implemented in the scenario.

\section{Impact of the trade war on trade, value added and prices}

The purpose of our exercise is to quantify how exports, imports, value added, factor income and prices deviate from their baseline value as a result of the trade war, with a focus on belligerents. We consider a central scenario comprising the Section 232 and retaliation, as well as the Section 301 and retaliation. In this central scenario we model the actual shock of the sanctions and retaliation, with the finest level of detail. Two alternative scenarios are modelled in less detail, given the uncertainty surrounding the sanctions that could be enforced: a further US escalation, through Section 232 on automobile, versus the removal of bilateral tariffs on industrial goods between the US and the EU (agriculture and vehicles excluded). Beyond the possible outcomes of alternative policies, these two additional, and somehow extreme, scenarios allow us to further detail the mechanisms impacting GVCs. The three scenarios are detailed in this section, before discussing the aggregate impact of the trade war and, importantly for our purpose, the impact of the trade war on GVCs, producer prices, trade and value added.

\subsection{The scenarios}

The first component of our central scenario is the Section 232 and the related retaliation. In April 2017, the US President instructed Commerce Secretary Wilbur Ross to investigate whether steel and aluminium imports were threatening the US national security. These investigations, covered by Section 232, concluded to a threat, opening the door to a Presidential decision on protection. While, in the past, the US had generally mobilized Section 232 against oil exporters considered as threatening the US security, ${ }^{19}$ tariffs were announced in March 2018 against almost all exporters of aluminium and steel to the US (the main ones being the European Union, Canada and Mexico). As a result, tariffs on aluminium imposed by the US increased by 10 p.p. A partial

\footnotetext{
${ }^{17}$ We do not consider changes in the MFN rates following 2013. In particular, the decreases in MFN tariffs implemented by China in 2018 and 2019 are neither taken into account in the baseline nor in the policy scenarios.

${ }^{18}$ We represent a soft Brexit by leaving the tariffs applied by the UK and the EU unchanged, while increasing their bilateral NTMs to halve the preferential access of the UK to the EU market, and reciprocally

${ }^{19}$ See BIS (2007) for an analysis of the outcome of all investigations under Section 232 in the US.
} 
exemption was negotiated by Argentina, against a TRQ with a volume equal to the mean volume imported over the period 2015-2017. Australia was exempted from the increase in tariffs. For their part, tariffs on steel increased by 25 p.p. An exemption was again granted to Australia, while Argentina, South Korea and Brazil negotiated TRQs. ${ }^{20}$ Turkey also constitutes a special case, in the sense that tariffs on imports from this country increased by 50 p.p. from August 2018 to May 2019. ${ }^{21}$

Retaliatory tariffs were imposed by Canada, China, the European Union, Mexico, Russia and Turkey: we implement them as indicated from official sources (national legislation or notification to WTO). ${ }^{22}$ India notified to WTO retorsions in early 2018 , but their entry into force was delayed several times and finally applied in June 2019. Aware of the uncertainty surrounding these retaliations, we nevertheless consider them in our scenario.

To the best of our knowledge the present contribution is the only paper offering an impact assessment accounting for retaliation from Russia. We also account for the safeguard on imports of steel imposed by the EU in January 2019. ${ }^{23}$

The second series of measures to be taken into account under scenario 1 is related to the use of US Section 301 against China, which took place in several rounds after the release of the US administration investigation in March 2018. The argument used for limiting US imports from China is now about violation of intellectual property rights and unfair trade practices. The first round led to an increase in US tariffs on 50 USD bn of US imports from China in two phases starting July 2018 (16 and then 34 bn). China retaliated with additional 5\% to $25 \%$ tariffs (depending on the goods) on 50 USD bn of US exports. As a follow up, in September 2018, the US administration retaliated to the Chinese retaliation with a second round of $10 \%$ additional tariffs on USD 200 bn of US imports from China. A further move from $+10 \%$ to $+25 \%$, originally planned for January 2019 was then postponed to March 2019, and further postponed given the "progress" made in bilateral trade talks. However, after these first talks broke down, the increase finally took place in June 2019. China retaliated to this second round by imposing 10 additional percent (and then 25) of tariffs on USD 60 bn imports from the US. In September 2019, the last wave of additional tariffs entered into force, additional 15\% on USD 112 bn of goods imported from China. Chinese retaliation concerned US exports worth USD 29 bn and imposed addtional tariffs between 5 to $10 \%$. These additional tariffs were halved to $7.5 \%$ in February 2020 , as a sign of good will to celebrate the entry into force of the Phase One Deal. The conclusion of the deal also prevented a last tariff increase (the list 4B, additional 15\% on USD 160 bn imports from China), and the related Chinese

\footnotetext{
${ }^{20}$ The negotiated TRQs for steel are as follows. (i) Argentina: $135 \%$ of the average volume exported over 2015 - 2017 ; (ii) Brazil: the average volume exported over $2015-2017$ for semi-finished product and $70 \%$ of the average volume exported over $2015-2017$ for finished products; (iii) South Korea: $70 \%$ of the average volume exported over $2015-2017$.

${ }^{21}$ For the sake of simplicity, and because the tariffs are applied annually in our setup, we do not consider the temporary increase in the duties applied to Turkish steel exports. In the same vein, we do not take into account the removal of US GSP preferences to Turkey and India entered into force in May and June 2019, respectively.

${ }^{22}$ After the conclusion of the re-negotiation of the North American Free Trade Agreement, the additional duties between the US and Canada and Mexico (those imposed under Section 232 by the US and the following retaliations) were canceled in May 2019. We do not consider them in our scenarios. Retaliation from Turkey is considered after its revision in August 2018.

${ }^{23}$ The official list of products affected and details on the TRQs in place are given by two EU Commission regulations, available at https://eur-lex.europa.eu/eli/reg_impl/2018/1013/oj and http://data.europa.eu/eli/reg_impl/2019/159/oj.
} 
retaliation (increased tariffs on USD 45.5 bn of goods imported from the US, including the end of the exclusion of US autos and parts), scheduled for December 2019 but actually postponed until further notice.

Table 1 shows what could potentially be the main impacted sectors in the US-China bilateral trade in this scenario. Sectors are ranked using the simple criterion of the impacted tariff revenue (initial imports times tariff increase), which is indeed not the expected change (imports will decrease, conditional on the trade elasticity).

Starting with Chinese exports, Electronics is potentially the main impacted sector: USD 167 bn of exports will face an average tariff increasing from $0.3 \%$ to $13.4 \%$. Machinery is the second impacted sector, with a 17.8 percentage points increase in tariffs applied by the US on USD 103 bn of Chinese exports. Among all other sectors, tariff changes can be even larger, but trade is more limited. The best illustration of this is the automotive sector (here mainly parts and components, see Appendix E, table E.3), where a 21.2 percentage points increase in protection will only affect USD 14 bn of Chinese exports.

The potentially most impacted US sector is the Machinery industry, facing a 9.6 percentage point increase in Chinese tariffs on 29 bn of US exports. The Chemistry, Non Ferrous Metals and Oilseeds are also potentially seriously hit with a change in protection revenue of around $1.8 \mathrm{bn}$, closely followed by Electronics. The US car industry does not appear here since China cancelled in January 2019 the additional tariffs initially set to retaliate against US lists 1 to 3 .

As described above, the trade war initiated by the US administration is also impacting other exporters, in particular under Section 232: USD 6 bn of Iron and steel exported by EU 27 to the US are facing a 19.6 percentage points increase.

Retaliation from countries other than China has much smaller impacts since it affects smaller flows. Indeed, Fetzer and Schwarz (2019) and Blanchard, Bown and Chor (2019) recall that products affected by retaliation are mainly chosen in order to affect areas that supported D. Trump in the 2016 presidential election, i.e. based on political considerations.

This targeting pattern, combined with smaller amount of trade affected for countries other than China, results in retaliatory lists containing several small trade flows rather than being concentrated.

It is difficult to figure out how commercial tensions will evolve between Europe and the US. We will however consider two alternative scenarios; the purpose, here again, is to illustrate how the involvement of belligerents in GVCs is shaping the adjustment of sectors and potentially leading to value added - and thus income - losses. As we do not have the details of the possible sanctions and retaliations, we adopt a series of simple, although sensible, assumptions on targeted products.

Two additional, and somehow contradictory, elements could constitute the next episode of the current trade 
Table 1 - Scenario 1 - Trade value and protection: most impacted bilateral flows

\begin{tabular}{lllrrrrr}
\hline Sector & Exporter & Importer & \multicolumn{2}{c}{ Tariffs (in \%) } & & Trade & Change in prot. rev. \\
\cline { 3 - 4 } & & & & Reference & Scenario & (USD bn.) & (USD bn.) \\
\hline Electronics & China & USA & 0.3 & 13.4 & 167 & 21.9 \\
Machinery & China & USA & 1.5 & 19.3 & 103 & 18.3 \\
Oth. manuf. & China & USA & 1.5 & 12.3 & 69 & 7.5 \\
Textile & China & USA & 11.4 & 20.8 & 65 & 6.1 \\
Chemistry & China & USA & 2.7 & 19.0 & 36 & 5.9 \\
Metal prod. & China & USA & 2.1 & 21.4 & 19 & 3.7 \\
Vehicles & China & USA & 1.0 & 22.2 & 14 & 3.1 \\
Machinery & USA & China & 4.1 & 13.7 & 29 & 2.7 \\
Chemistry & USA & China & 4.9 & 14.2 & 23 & 2.1 \\
Non ferrous met. & USA & China & 0.7 & 19.6 & 10 & 1.9 \\
Oilseeds & USA & China & 1.5 & 16.9 & 13 & 1.9 \\
Electronics & USA & China & 1.3 & 9.5 & 21 & 1.7 \\
Iron and steel & EU 27 & USA & 0.2 & 19.8 & 6 & 1.3 \\
Oth. manuf. & USA & China & 2.8 & 12.8 & 13 & 1.3 \\
Food & China & USA & 5.0 & 24.7 & 6 & 1.2 \\
Minerals & China & USA & 4.2 & 19.9 & 7 & 1.1 \\
Food & USA & China & 9.1 & 26.7 & 6 & 1.1 \\
\hline
\end{tabular}

Notes: Percentage deviation from the baseline in 2030 , in volume. Volumes are based on a Fisher index. Sectors are ranked by decreasing impact on tariff revenue.

Source: BACI (2017), MAcMap-HS6, authors' calculation.

tensions. On the one hand, further escalation, through Section 232 on automobile: the argument invoked is that massive imports of autos and their parts, in particular from the EU, are threatening US security. The decision on whether to apply additional tariffs to US imports (from all over the world, with the probable exception of Canada and Mexico) was initially due in March 2019. It has been postponed to November 2019. By the end of March 2020, no decision had been taken. In the US, whether it was still legally possible to implement additional tariffs without opening a new investigation was debated, while the EU trade representative, in the days following the absence of the announcement of new tariffs, still considered that the threat was not entirely gone. With this respect, the EU announced that if the US apply additional tariffs, she would retaliate with sanctions on USD 50 bn of exports from the US to the EU.

In parallel, the EU and the US announced they would launch negotiations to eliminate tariffs on their bilateral trade of industrial goods, excluding automobile (as well as agriculture) according to the Joint EU-US Statement following J.C. Juncker's visit to the White House, in July 2018. Here again, the situation was close to a status quo as of March 2020.

Scenario 2 tentatively adds the possible measures on imports of automobiles and their parts, to be taken under Section 232 (i.e. invoking national security to motivate them), to scenario 1 . We assume that the US increase their tariffs by $25 \%$ for all the exporters, with the exception of Canada and Mexico, and that the main exporters of autos to the US retaliate, increasing by 25 p.p. the tariffs on the main products they imports from the US (excluding energy and pharmaceutical products). The value of imports affected by retaliation is equivalent to 
the value of exports targeted by the section 232 .

Finally, scenario 3 simulates the removal of bilateral tariffs on industrial goods between the US and the EU (agriculture and vehicles are excluded), while measures related to Section 232 on steel and aluminium against partners other than the EU and to Section 301 against China remain in place.

As said, the Phase One Deal between the US and China hardly reduces tariffs: US tariffs on imports of parts and components from China put in place by the first three 301 waves are maintained (25 p.p. on imports worth USD 250 bn), while China cut in half only retaliatory tariffs imposed on US exports in September 2019 formally independently from the signed deal. The deal basically avoids, at least temporarily, a further escalation and imposes managed trade on the top of maintained tariffs, China committing to import more goods from the US. This said, due to the Covid-19 crisis, China announced it would be difficult to reach the import targets and fulfill its commitments. Accordingly, we disregard a managed trade scenario given this multi-faceted uncertainty and focus on an up-to-date collection of tariffs and VERs as of February 2020.

We show in table 2 what are the sectors targeted by these pending policies: either a trade war extended to the automobile sector, or a negotiation aiming to phase out the industrial tariffs between the EU and the US. In the upper panel, American sanctions on automobile show up as a very important issue for the USD 49 bn EU 27 exports. Using the simple metric of tariff revenue, the order of magnitude is approximatively half of what we observed in Electronics for China in table 1 (here: USD 11.7 bn for Automobile). Japan would be even more impacted (resp. $13.1 \mathrm{bn}$ ). The EU should retaliate in the same sector or in a similar one, such as Other transport equipment, but the damage to the US would be much lower. ${ }^{24}$

In the bottom panel of table 2, we show what would be the impact on tariff revenues of a phasing out of industrial tariffs between EU and the US. Not surprisingly, given the initial low level of tariffs, there is not much action there. The largest impact is on Chemistry and the magnitude of it is below USD 2 bn of tariff revenue on both sides of the Atlantic. Other sectors potentially impacted would be Machinery and Textile, for even lower amounts. Accordingly, this negotiation is worth having just for sake of cooling the protectionist tensions, but it would not deliver much in case of success.

\subsection{Aggregate impacts of the trade war}

What is the overall impact of detailed scenario 1 in our model featuring GVCs and imperfect competition? The trade war will reduce drastically bilateral trade between the two main actors of the conflict, and will lead to a reorientation of exports (although in the case of steel and aluminium, EU safeguards limit this adjustment), ultimately reducing world trade by $-0.96 \%$ and world GDP by $-0.11 \%$. These expected mechanisms are indeed

\footnotetext{
${ }^{24}$ Given the current dispute regarding the aircraft subsidies, one might guess that the EU would not introduce this sector in the retaliation to the automobile battle. But we disregard this question mark here and the sector Other transport equipment is hit by retaliation in our exercise.
} 
Table 2 - Scenarios 2 and 3 - Trade value and protection: most impacted bilateral flows

\begin{tabular}{|c|c|c|c|c|c|c|}
\hline \multirow[t]{2}{*}{ Sector } & \multirow[t]{2}{*}{ Exporter } & \multirow[t]{2}{*}{ Importer } & \multicolumn{2}{|c|}{ Tariffs (in \%) } & \multirow{2}{*}{$\begin{array}{c}\text { Trade } \\
\text { (USD bn.) }\end{array}$} & \multirow{2}{*}{$\begin{array}{c}\text { Change in prot. rev } \\
\text { (USD bn.) }\end{array}$} \\
\hline & & & Reference & Scenario & & \\
\hline \multicolumn{7}{|c|}{ Scenario 2: Sanctions on automobile and retaliations } \\
\hline Vehicles & Japan & USA & 1.5 & 26.4 & 52 & 13.1 \\
\hline Vehicles & EU 27 & USA & 1.8 & 25.7 & 49 & 11.7 \\
\hline Oth. transp. eq & USA & EU 27 & 1.5 & 20.0 & 36 & 6.7 \\
\hline Vehicles & Korea & USA & 0.9 & 25.9 & 21 & 5.2 \\
\hline Vehicles & UK & USA & 1.6 & 26.2 & 10 & 2.4 \\
\hline Machinery & USA & Japan & 0.2 & 16.1 & 15 & 2.4 \\
\hline Oth. transp. eq & USA & Japan & 0.0 & 22.9 & 7 & 1.6 \\
\hline Chemistry & USA & Japan & 1.5 & 11.8 & 14 & 1.4 \\
\hline Food & USA & Japan & 22.9 & 40.2 & 7 & 1.3 \\
\hline \multicolumn{7}{|c|}{ Scenario 3: Phasing out of industrial tariffs between the EU and the US } \\
\hline Chemistry & EU 27 & USA & 2.0 & 0 & 95 & -1.9 \\
\hline Chemistry & USA & EU 27 & 3.0 & 0 & 56 & -1.6 \\
\hline Machinery & EU 27 & USA & 1.0 & 0 & 90 & -0.9 \\
\hline Textile & EU 27 & USA & 9.0 & 0 & 9 & -0.8 \\
\hline Machinery & USA & EU 27 & 1.5 & 0 & 52 & -0.8 \\
\hline
\end{tabular}

Notes: Percentage deviation from the baseline in 2030 , in volume. Volumes are based on a Fisher index. Sectors are ranked by decreasing impact on tariff revenue.

Source: BACI (2017), MAcMap-HS6, authors' calculation.

present in our results, and the more so that we rely on a global model taking stock of all relative price changes and third country effects. Table 3 gives an overview of these results (we present the results for Germany instead of EU 27 in order to avoid obvious problems of aggregation, e.g. on wages).

The first aggregate impact of the trade war is to dramatically increase US tariff revenues: they actually double $(+106.59 \%){ }^{25}$ The improvement in US terms of trade is limited $(+0.27 \%)$ as opposed to the usual optimal tariff agreement. US exports to the world post a $7.88 \%$ decrease as a result of sanctions and reduced competitiveness: the cost of imported intermediate inputs increase which translates into increases in producer prices. We detail this mechanism below. American farmers are adversely affected by Chinese sanctions (return to land records a $-5.3 \%$ drop) and workers are also negatively affected in real terms, although white collars suffer more than blue collars. Ultimately, limited benefits accrue to the capital owners despite the reduced competition on the US market (return to capital increases by $0.12 \%$ ). All in all, the US GDP is facing a USD 95 bn decrease $(-0.41 \%)$.

Overall Chinese exports are hit by a modest $-4.23 \%$ decrease, ${ }^{26}$ meaning that China manages to compensate reduced access to the US market by redirecting exports, although be it at the expense of reduced producer prices. Chinese terms of trade decrease as a consequence $(-1.2 \%)$, while workers and capital owners lose to the benefits of farmers. Overall the Chinese GDP is facing a USD 142 bn $(-0.59 \%)$ reduction.

\footnotetext{
${ }^{25}$ All figures are percentage deviations from the baseline in 2030 , in volume, i.e. not taking into account price effects.

${ }^{26}$ In the simulation exercises, the regional aggregation gathers China and Hong Kong. For the ease of the exposition, we write about impacts for China when referring to the results for the region China and Hong Kong. See Appendix D for details on the aggregation.
} 
Table 3 - Scenario 1 - Main aggregate results for selected countries

\begin{tabular}{lrrrrrrr}
\hline & \multicolumn{1}{c}{ USA } & \multicolumn{1}{c}{ China } & Canada & Germany & Japan & Korea & Mexico \\
\hline Total tariff revenue & 106.59 & 9.46 & 3.92 & 2.00 & 0.77 & 0.08 & 8.49 \\
Exports & -7.88 & -4.23 & 1.36 & 0.31 & 1.07 & 0.08 & 3.38 \\
GDP & -0.41 & -0.59 & 0.30 & 0.04 & 0.12 & -0.01 & 0.37 \\
Terms of trade & 0.27 & -1.20 & -0.01 & 0.06 & 0.05 & 0.29 & 0.95 \\
Real return to capital & 0.12 & -0.14 & -0.22 & -0.03 & -0.01 & 0.01 & 0.17 \\
Real return to land & -5.30 & 1.02 & -0.85 & 0.18 & 0.06 & -0.03 & -1.34 \\
Skilled real wages & -0.43 & -1.14 & 0.52 & 0.07 & 0.12 & 0.04 & 0.49 \\
Unskilled real wages & -0.24 & -0.78 & 0.31 & 0.07 & 0.12 & 0.02 & 0.42 \\
\hline
\end{tabular}

Notes: Percentage deviation from the baseline in 2030, in volume. Volumes are based on a Fisher index.

Source: MIRAGE-VA, authors' calculation.

Korea and Japan are hardly affected. The presence of GVCs introduces a potential additional benefit for Canada and Mexico, beyond the standard trade diversion argument linked to their participation in the NAFTA. Canada and Mexico are not targeted by Section 232, except initially; as a result, production is reallocated in assembly lines located in these two countries.

Certain bilateral relationships or certain sectors in China, in the US or in Europe will be severely affected (see details for China and the US in Appendix E, tables E.5 and E.6, resp.). Chinese exports to the US record a $-50.4 \%$ drop. China however reorients its exports firstly towards Canada $(+13.1 \%)$ and Mexico $(+12.2 \%)$, less substantially towards Europe (e.g. $+6.4 \%$ towards the UK or $+4.9 \%$ towards Germany). US exporters record a $-38.2 \%$ decrease in their exports to China but, contrary to their Chinese competitors, do not compensate these losses on other markets. US exporters lose ground on all markets in the world due to competitiveness losses and retaliation by certain destination countries. Losses amount to e.g. $-4.2 \%$ in Korea and Japan, and to $-5.5 \%$ in Germany.

Consistently with the elements on the increase in protection given in table 1 , Chinese exports of Electronics to the US market suffer a $-57.1 \%$ drop. This is even worse for intermediate products targeted by US sanctions $(-71.9 \%)$. And with the exception of the resilient Mexican market $(+7.4 \%$ in total, driven by a $+11.7 \%$ increase in exports of intermediate products $)$ and ASEAN market $(+0.3 \%$ overall and $+2.8 \%$ in intermediate products), this is not compensated elsewhere: Chinese exporters loose ground everywhere in this sector, as a result of the disruption of global value chains. Losses range from $-2.2 \%$ in the region Other Oceania, to $-1.4 \%$ in Germany and to a tiny $-0.04 \%$ in Brazil. This situation contrasts with Machinery where the drop in Chinese exports to the US market $(-61.7 \%)$ is cushioned by an increase in Chinese exports on other markets (and $+13 \%$ to Canada and Mexico). In the car industry, the toll on Chinese exports to the US is important also $(-53.5 \%)$, but here again cushioned by a redirection of exports to other markets (especially Canada $+13.4 \%$ and Mexico $+7.4 \%$ ). The same reasoning applies to Chemistry, in which Chinese losses on the US market amount to $-52.7 \%)$. 
US exports of vehicles are severely hit, even if China cancelled its retaliation in January 2019.

Producers located in the US suffer an increase in their production costs due to sanctions affecting intermediate consumptions produced by other sectors and bear market losses on every destination. Cuts in exports are sizeable towards China $(-21.3 \%$, driven by a fall by $-25.7 \%$ in assembled cars, greater than the reduction in parts and components $-14.6 \%)$. Japan $(-9.4 \%)$, Korea $(-9 \%)$ or Germany $(-8.1 \%)$. In Machinery, Chinese retaliations are effective, imposing a $-56.7 \%$ drop in US exports. Again, whatever the foreign market, US exports in the Machinery sector loose competitiveness because of increased production costs. The same mechanism is observed for Non ferrous metals, but here magnified as a result of retaliations: US exports to China record a $-80 \%$ drop, and two-digit losses are observed everywhere but on the Canadian and Mexican markets.

\subsection{Impact of the trade war on GVCs and producer prices}

We now turn to the core argument of this paper. By imposing tariffs on imported inputs and by taxing domestic value added contained in imports of final goods, the trade war not only hurts the targeted countries but also the country imposing the tariffs.

The first insight in this complex chain of effects is provided by the outcome of protection in terms of trade in final versus intermediate goods. Figure 1 reports the impacts on US bilateral trade flows with major trading partners, distinguishing between trade in final and intermediate products. ${ }^{27}$ We firstly observe a massive cut in US imports of intermediate inputs, parts and components from China (i.e. a $-61 \%$ drop, USD -234 bn). An almost equivalent value of imports of final goods disappear (USD -221 bn), but this represents "only" $-43 \%$ of US imports of final goods from China. The difference here observed reflects the attempt of the US administration to disrupt GVCs while limiting the direct cost of the trade war beard by US consumers. The Chinese cut in imports from the US is much more limited, but most of it is intermediate products (around three quarters of the impact in dollar terms, $79 \%)$ despite relative changes of similar magnitude $(-40 \%$ for intermediate and $-33 \%$ for final goods). We finally observe that US imports of final goods somehow diversify their origin, to the benefit of Korea, Japan, Mexico, Germany and France, Brazil or Canada to a lesser extent. This pattern is not observed for intermediate goods, or to a much lesser extent, because reorganizing value chains is difficult.

The second piece of the puzzle on the US side is how producer prices react to (i) the increase in the price of intermediate inputs, (ii) the drop in demand on export markets due to retaliations and (iii) the reduced competition in the US market due to border protection. This is shown in the right panel of table 4 , at the sectoral level. The evidence is clear-cut. Farm products seriously hit by retaliations respond to reduced market

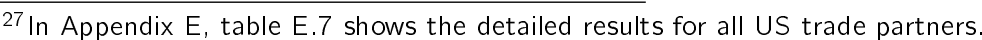


Figure 1 - Scenario 1 - Impacts on US trade flows (variations with respect to the baseline, in 2030)

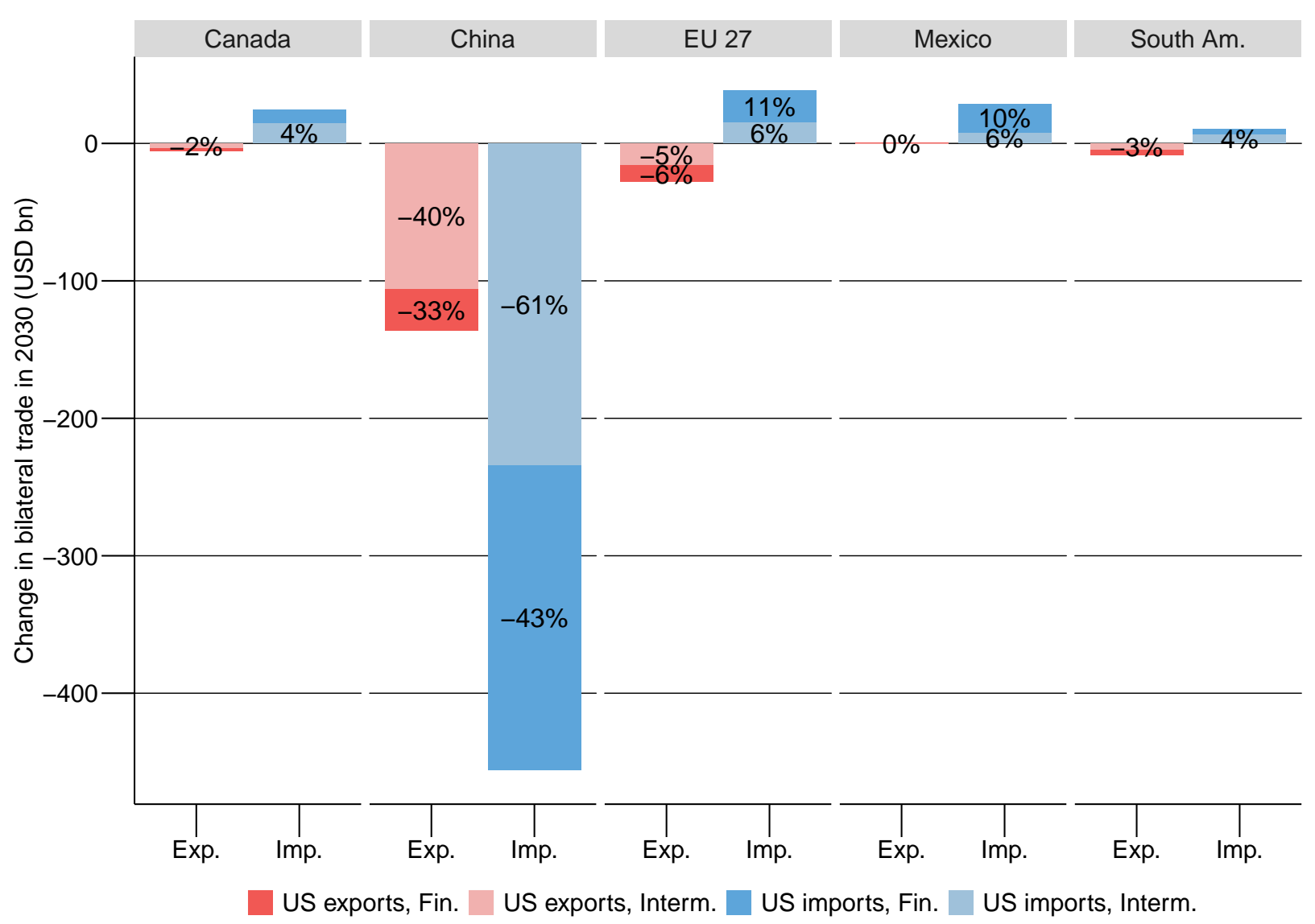


Table 4 - Changes in production price and value added, by sector

\begin{tabular}{|c|c|c|c|c|c|c|}
\hline \multirow[b]{3}{*}{ Sector } & \multicolumn{3}{|c|}{ China } & \multicolumn{3}{|c|}{ USA } \\
\hline & \multirow{2}{*}{$\begin{array}{c}\text { Prod. price } \\
(\%)\end{array}$} & \multicolumn{2}{|c|}{ Value Added } & \multirow{2}{*}{$\begin{array}{c}\text { Prod. price } \\
(\%)\end{array}$} & \multicolumn{2}{|c|}{ Value Added } \\
\hline & & (USD bn) & $(\%)$ & & (USD bn) & $(\%)$ \\
\hline Anim. agriculture & -1.3 & 1.8 & 0.3 & 0.5 & -0.9 & -2.4 \\
\hline Cereals & -1.1 & 6.5 & 2.1 & 0.3 & -3.4 & -3.7 \\
\hline Chemistry & -1.2 & 6.2 & 0.9 & 0.8 & -13.2 & -2.4 \\
\hline Coal & -1.2 & 1.5 & 0.9 & 0.4 & -0.6 & -2.8 \\
\hline Electricity & -1.2 & 0.2 & 0.1 & 0.9 & -0.7 & -0.3 \\
\hline Electronics & -0.9 & -42.9 & -9.9 & 1.4 & 4.2 & 7.3 \\
\hline Fiber crops & 0.0 & 1.5 & 7.9 & -1.2 & -1.1 & -7.7 \\
\hline Food & -0.7 & -1.2 & -0.3 & 0.5 & -4.8 & -1.5 \\
\hline Gas & -0.5 & 0.7 & 0.0 & 2.6 & 3.3 & 1.4 \\
\hline Iron and steel & -1.2 & -1.5 & -0.4 & 1.1 & 7.5 & 9.4 \\
\hline Machinery & -1.2 & -16.3 & -1.3 & 1.0 & 13.0 & 1.9 \\
\hline Metal prod. & -1.3 & -4.4 & -1.7 & 1.0 & 7.0 & 3.6 \\
\hline Minerals & -1.3 & 3.1 & 0.5 & 0.7 & -0.5 & -0.4 \\
\hline Non ferrous met. & -1.2 & 2.6 & 1.2 & 1.1 & -2.9 & -5.9 \\
\hline Oilseeds & 1.2 & 4.2 & 11.7 & -3.5 & -8.2 & -13.2 \\
\hline Oth. crops & -0.2 & 0.4 & 9.5 & 0.2 & -1.2 & -3.6 \\
\hline Other agri. & -0.9 & 1.0 & 0.3 & -3.2 & -0.7 & -2.5 \\
\hline Other manuf. & -1.2 & -6.2 & -1.1 & 0.6 & 8.3 & 1.6 \\
\hline Petroleum & -0.6 & -0.3 & -0.1 & 0.4 & -0.9 & -0.3 \\
\hline Services & -1.7 & -19.7 & -0.2 & 0.5 & -15.2 & -0.1 \\
\hline Sugar & -1.8 & 0.1 & 0.4 & 0.8 & -0.0 & -1.6 \\
\hline Textile & -1.1 & 4.5 & 1.3 & 0.8 & -1.0 & -0.6 \\
\hline Transp. eq. & -1.3 & 2.9 & 1.7 & 0.9 & -7.7 & -5.0 \\
\hline Transport & -1.4 & 2.6 & 0.2 & 0.6 & -2.6 & -0.4 \\
\hline Veg. and fruits & -1.5 & 7.2 & 1.2 & -0.1 & -2.8 & -5.0 \\
\hline Vehicles & -1.2 & -2.7 & -0.7 & 1.2 & -4.2 & -2.4 \\
\hline
\end{tabular}

Note: Variations in the policy scenario, in volume, with respect to the reference scenario, based on a Fisher index.

Source: MIRAGE-VA, authors' calculations.

access by producer prices cuts. This affects negatively US terms of trade and partially explains why the usual tariff optimal argument did not show up in our aggregate results. The drop in producer prices is of $-3.5 \%$ for Oilseeds, the agricultural sector most affected by the Chinese retaliations. For the sectors most protected by the tariffs, the net effect of the three mechanism listed here is an increase in the producer price: $+1.4 \%$ in the Electronics sector, $1.1 \%$ in Aluminum and for Iron and steel, $0.8 \%$ in Chemistry. This has indeed cascading effects on automotive $(+1.2 \%)$ or Metal products $(+1.0 \%)$ and Other manufacturing $(+0.6 \%)$.

China offers in the left panel the mirror image of the US: producer prices increase in sectors benefiting from Chinese retaliation (e.g. Oilseeds $+1.2 \%$ ). In other sectors, Chinese producers have to reduce their production prices (Machinery $-1.2 \%$, Chemistry $-1.2 \%$, Electronics $-0.9 \%$ ). This indeed contributes to the observed deterioration of the Chinese terms of trade. In contrast, as expected, we observe in Appendix table E. 8 that no significant change in prices could be observed in Germany.

The last piece of evidence is the outcome of these adjustments in terms of value added (in volume, i.e. at 
constant prices). The aggregate negative effect on US GDP (hence on US aggregate value added) is the result of very diverse impacts of the trade war at the sectoral level. Sectors hit by retaliation suffer, as expected. We record a $-13.2 \%$ drop in the value added in the Oilseeds sector, and similarly a $-7.7 \%$ drop in the value added of the Fiber crops sector. At the other extreme, Iron and steel protected by article 232 exhibit a $+9.4 \%$ increase in their value added. The Electronics sector also records a $+7.3 \%$ in its value added. For Metal products and Machinery, the increase is more modest (resp. $+3.6 \%$ and $+1.9 \%$ ). Provided that these sectors reduce their exports, it means that the domestic market is protected enough to pass the increase in production costs to the final consumer. The car industry is in a more adverse situation, combining increased costs for steel and aluminium, increased costs on components imported from China and lastly Chinese retaliations on final products.

In China, the Electronics sector is the most affected in terms of value added $(-9.9 \%)$. Metal products and Machinery are affected to a lesser extent $(-1.7 \%$ and $-1.3 \%$ respectively). Sectors benefiting from the retaliation enjoy an increase in their value added (Oilseed $+11.7 \%$, Fiber crops $+7.9 \%$ ).

These results are summed up in Figure 2, where we plot the percentage changes in the value added of sectors in the US and China. The upper-right quadrant corresponds to sectors winning in both countries. Not surprisingly, this quadrant is empty, meaning that the trade war fails to create value.

Turning clockwise, the bottom right quadrant shows industries winning in the US at the expense of their competitors in China. Clearly, most of the action is in the Electronics sector, where the Chinese value added records a 9.9\% decrease, while the US gain $7.3 \%$. Chinese losses are even more impressive, with a USD 42.9 bn drop, while US gains reach only USD 4.2 bn. Accordingly, this industry will record a massive destruction of value. In the Iron and steel sector US gains are also sizeable ( $9.4 \%$ of value added, or a USD 7.5 bn increase) but the impact on China is negligible, even taking on board, as we did, European safeguards. China was already barred from the US market with anti-dumping before the trade war, and the new measures have little impact. Finally, in relative terms, Machinery and Metal products post modest gains for the US and modest losses for China. ${ }^{28}$

In the quadrant where the two countries loose, the Food sector shows up, but for small changes, in particular in China, together with the Vehicle sector. The latter looses more in the US $(-2.4 \%$, corresponding to USD -4.2 bn) than in China $(-0.7 \%$, i.e. USD $-2.7 \mathrm{bn})$, notwithstanding the cancellation of Chinese retaliations on this sector. Indeed, the US automotive industry suffers from a loss of competitiveness on all markets because of the increase in its production costs, caused by higher prices for steel and Chinese car components.

Lastly, the quadrant where the US loose and China gains is very populated: it gathers 16 out the 26 sectors

${ }^{28}$ Changes in absolute terms in the Machinery sectors are large due to the initial size of this sector, USD +13 bn in the US and USD -16.3 bn in China. 
we consider in the US economy. These are the sectors mainly hit by Chinese retaliation. First, the US are hit heavily in Oilseeds by Chinese retaliations: US value added records a $-13.2 \%$ drop (or USD -8.2 bn), ${ }^{29}$ which is in the order of magnitude of US gains in the Iron and steel sector. US producers of Fiber crops, Vegetables and fruits, Cereals and Other crops also pay their tribute. Among industrial sectors Chemistry is hit by a $-2.4 \%$ drop in value added, representing USD -13.2 bn given the size of this sector. The same remark pertains to the US industry of Transport equipment other than automobiles, posting a $-5.0 \%$ and USD -7.7 bn drop in value added. The latter sector suffers, like the one of Vehicles, from reduced competitiveness in the US as well as in third markets, because of the increased prices of intermediate consumptions.

Figure 2 - Scenario 1 - Relative changes in value added, by sector, in 2030 (\%)

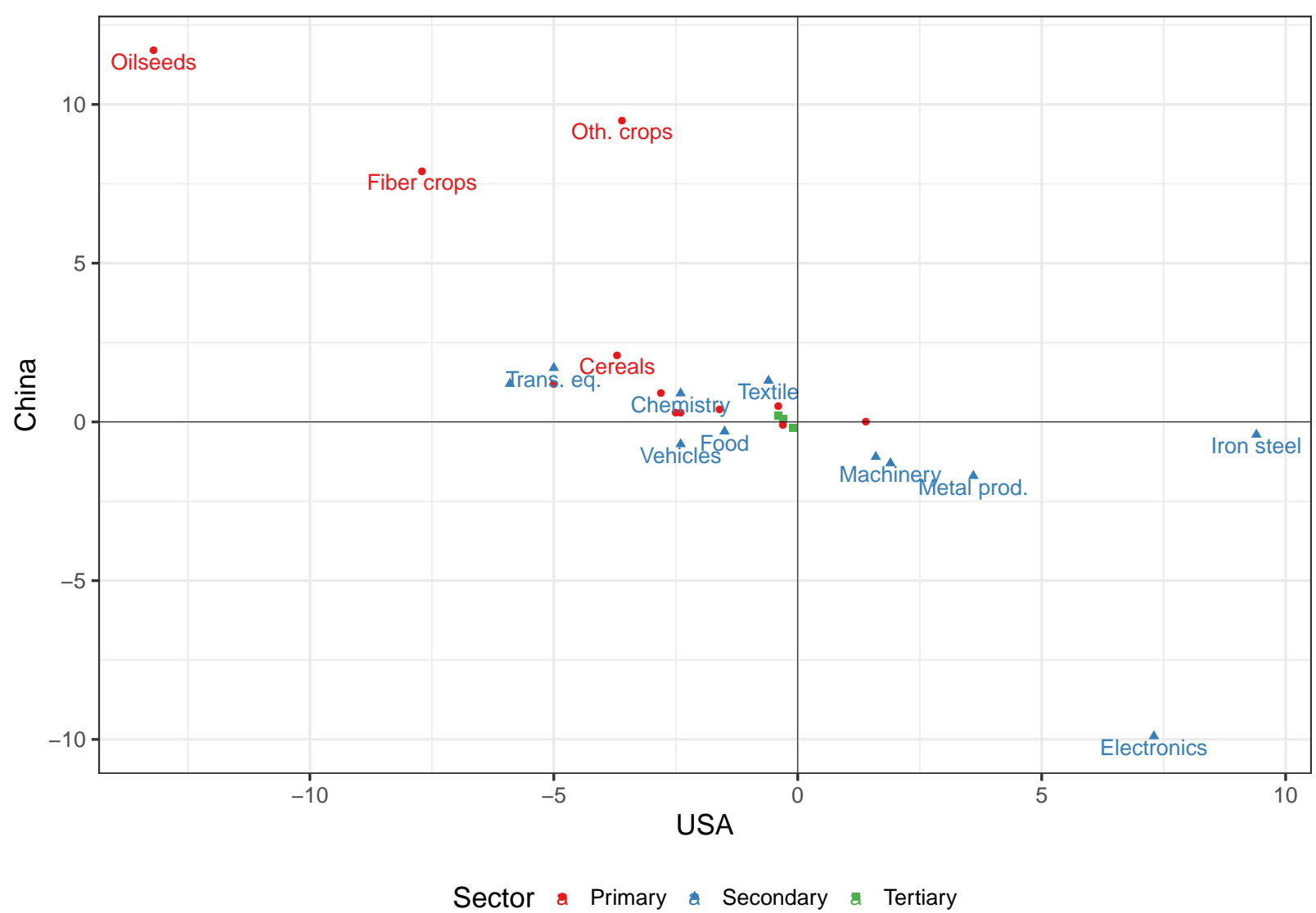

\subsection{Impacts of pending sanctions and retaliations on trade and value added}

We now examine briefly how the pending sanctions and retaliations would modify the results of our central scenario. ${ }^{30}$

The prospects of another battle in the automobile industry combined with the previous series of sanctions and retaliation (as in scenario 2) are indeed firstly a massive decrease in Japanese car ( $-72.0 \%)$ and car components

\footnotetext{
${ }^{29}$ We do not take into account any exceptional compensating subsidy granted to the agricultural sector.

${ }^{30}$ In the following, we focus on the impacts on trade and value added, mainly at the sector level. In the Appendix, tables E.9 and E. 10 provide the main aggregate results for selected countries obtained in scenarios 2 and 3 , respectively.
} 
$(-69.8 \%)$ exports to the US. European exports of cars and components to the US are also affected; especially Germany would be hit by a massive drop in exports (resp. $-49.0 \%$ and $-58.9 \%$ ). Even if these sectoral impacts are similar, overall Japan suffers more than the EU in scenario 2 since Vehicles represent a much larger share $(64 \%)$ in its total exports to the US than in the EU $(8 \%)$. Beyond these results, we are interested in the additional impact of these measures on trade in final versus intermediate goods, and ultimately on value added. To proceed, results are no longer presented with respect to the baseline, but with respect to scenario 1.

Under scenario 2, and compared to scenario 1, the first striking result illustrated in Figure 3 is the reorientation of US imports of final goods (mainly assembled cars) to the benefit of NAFTA, especially Canada $(+23 \%)$, at the expense of the EU $(-6 \%)$ and, mainly, Japan $(-45 \%$, i.e. USD $-61 \mathrm{bn})$. Due to the presence of integrated value chains within the NAFTA, this induces an expansion of US exports of parts and components of vehicles to the two assembly platforms - Canada and Mexico. In other words, one side effect of protecting the US market from European and Japanese competition for assembled cars is to increase US exports of parts and components to the Canadian and Mexican assembly plants of the regional car industry.

Figure 3 - Scenario 2 - Impacts on US trade flows (variations with respect to scenario 1, in 2030)

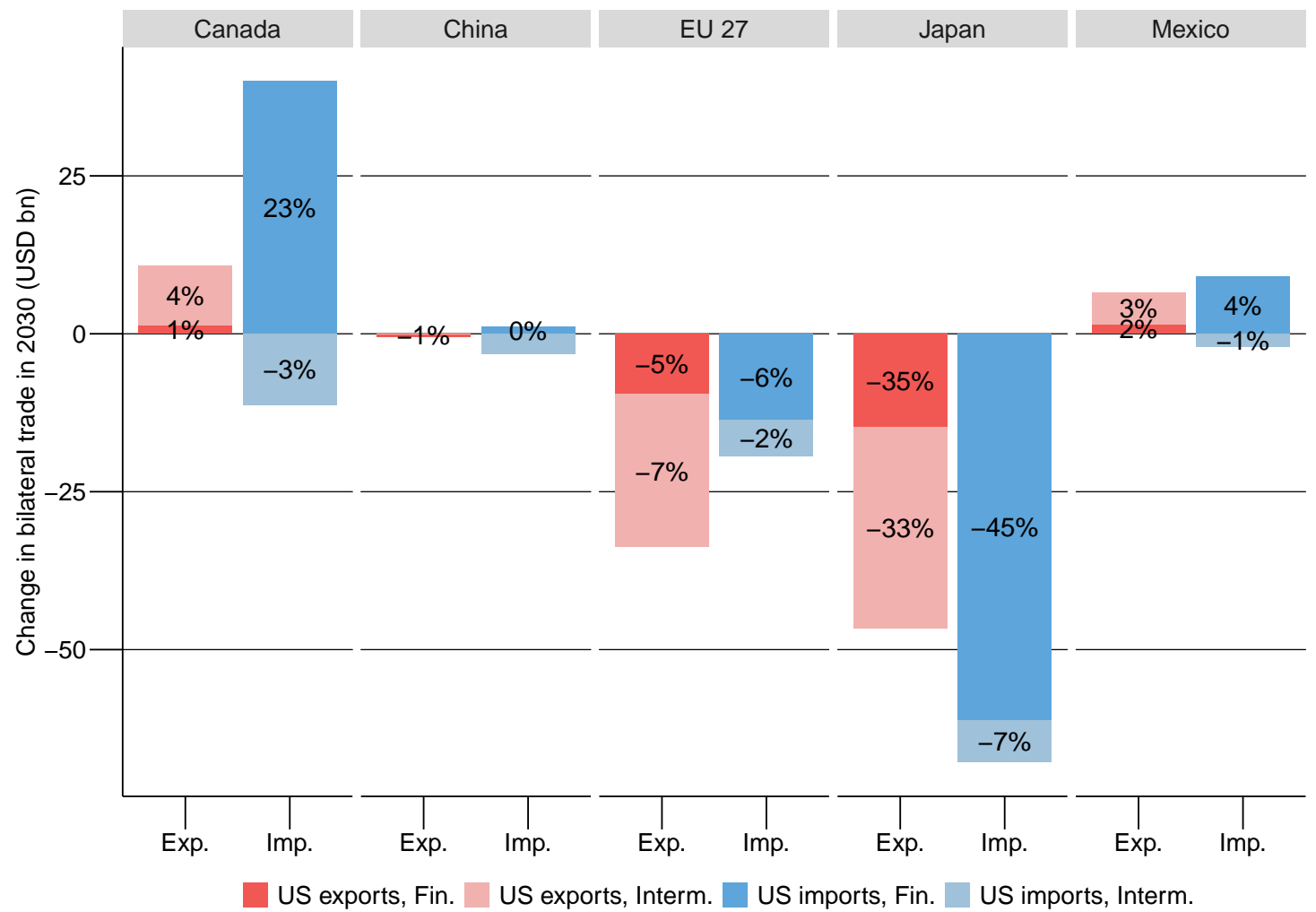

Let's now consider how scenario 3 (a phasing out of bilateral EU-US tariffs for manufactured products, excluding cars) would modify the impact of the trade war represented under scenario 1 . The potential impact on bilateral trade flows with the US is shown in Figure 4. Cooling the trade tensions would have no visible impact on countries other than the EU and the US. US exports of intermediate goods to the EU would record a significant $10 \%$ increase compared to a steady trade war (as in scenario 1 ), meaning an increase by $5 \%$ with respect to 
the baseline, instead of a decrease by $6 \%$ in scenario 1 , as shown in figure 1 . At the same time, EU exports of intermediate products to the US would increase by the same order of magnitude. Interestingly, trade in intermediate goods, in both directions, would increase by more than trade in final goods, mirroring the fact that the two sides of the Atlantic are deeply connected through GVCs.

Figure 4 - Scenario 3 - Impacts on US trade flows (variations with respect to scenario 1, in 2030)

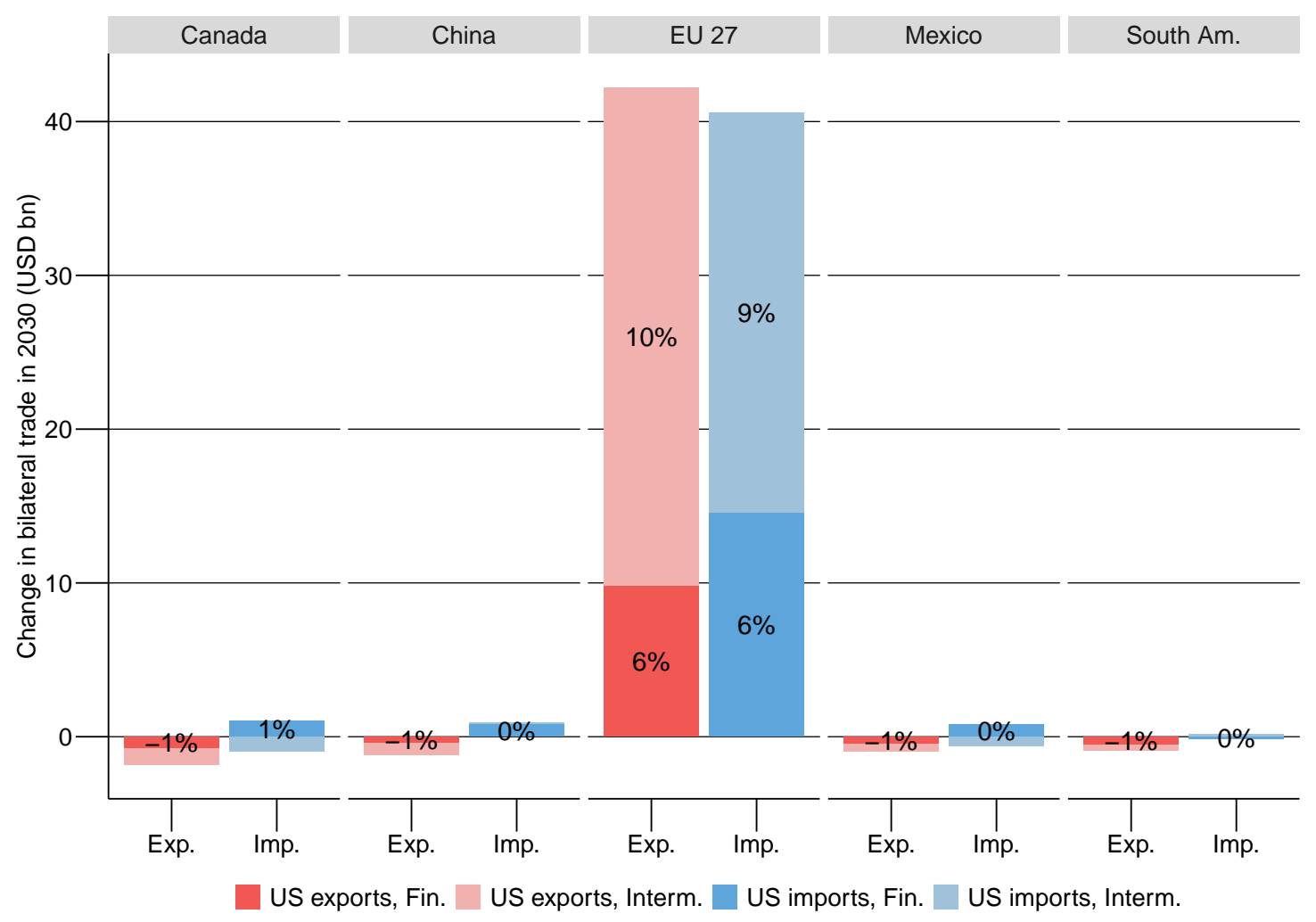

Finally, the impact of scenario 3 on value added is, as expected, limited. For instance, none of the industrial sectors in Germany or France records a change in value added above USD 0.5 bn, with the exception of Machinery in Germany (+2 bn). 


\section{The political economy of a trade war in presence of GVCs}

We have shown how the integration of economies throughout GVCs was shaping the impacts of a trade war. When trade in intermediate goods is affected - directly or indirectly - by sanctions or retaliations, the economic impact is transmitted throughout the value chain. In turn, the imposing country can be hurt by its own policy, because domestic components are present in imported final products, or because foreign components enter as an input in the production of exported products. The main message of our exercise is that GVCs are nowadays so prevalent that a trade war is costly for all belligerents. This said, the next question is why did the US engage in costly policies putting their own competitiveness at risk? Motivations going beyond the contribution of this paper could indeed be at stake, e.g. imposing losses to China as a retaliation for presumed intellectual property theft. However, it might be a more subtle move, consistent with political economy motives. Section 232 can indeed support the brick-and-mortar factories; but what about Section 301? The related sanctions and retaliations are profoundly reshaping the sectoral value added of belligerents, as illustrated above. Such large shifts of value added will necessarily be transmitted to the compensation of production factors within sectors. Recall for instance that we expect a USD 13 bn increase in the value added of Machinery in the US, or a 4.2 bn increase in the value added of Electronics. This contrasts with a -7.7 bn decrease in value added in Other transport equipment, or -13.2 bn decrease in Chemistry. ${ }^{31}$

The next step is to analyse the impacts on production factors employed in the different sectors of sanctions, retaliations and their propagation throughout GVCs. Let's start with labor, recalling that we have two categories of workers, skilled and unskilled. We show in figure 5 the variations in the wage bill of each category of workers and in each sector in 2030 . These are deviations in constant dollars from the baseline. For sake of clarity we omit sectors in which the variation is small, and sectors are ranked by increasing impact on their wage bill. In our central scenario here presented, the largest increase in the wage bill is for Machinery (+ USD 8 bn). This leads to a similar $2.1 \%$ increase in the wage bill of skilled and unskilled workers.

Since wages (for a given skill level and in a given country) are common across sectors in our model, we can interpret the percentage changes in wage bills as job creation versus job losses (at constant wages and skill composition). ${ }^{32}$ In Iron and steel, the absolute change in the wage bill is smaller (4.4 bn), but corresponds again to a similar percentage increase for the two categories of workers (resp. 9.6 and $9.8 \%$ for skilled and unskilled). This increase of around $9 \%$ in the number of jobs in this industry is the largest impact in relative terms (just followed by Electronics with an additional $8 \%$ jobs). Metal products and Other manufactured products also create jobs, while most of the other sectors - and firstly Chemistry and Transport equipment - destroy jobs.

\footnotetext{
${ }^{31}$ As for farmers, the discussion is more complex due to subsidies received as compensation from the Federal level; we can thus hardly assume that the e.g. USD 8.2 bn loss of value added in Oilseeds will translate into an equivalent loss for the production factors engaged in this sector.

${ }^{32}$ Actually, the variation in US skilled real wages is $-0.43 \%$ in scenario 1 and $-0.58 \%$ if we add US sanctions on cars and induced EU retaliation. Figures are respectively $-0.24 \%$ and $-0.37 \%$ for unskilled wages. Hence, for instance, a $5 \%$ drop in the wage bill in Chemistry represents a less than $5 \%$ decrease in the number of jobs.
} 
The broad picture is accordingly that the ultimate impact of the trade war in the US is to displace workers from downstream (e.g. Vehicles) to upstream industries (e.g. Iron and steel). ${ }^{33}$ Lastly, considering agricultural products, Oilseeds and Fiber crops are the two more vulnerable sectors in terms of job losses. Vegetable and fruits, and Cereals follow.

Figure 5 - Scenario 1 - Changes in US wage bills, by sector, in 2030 (USD bn)

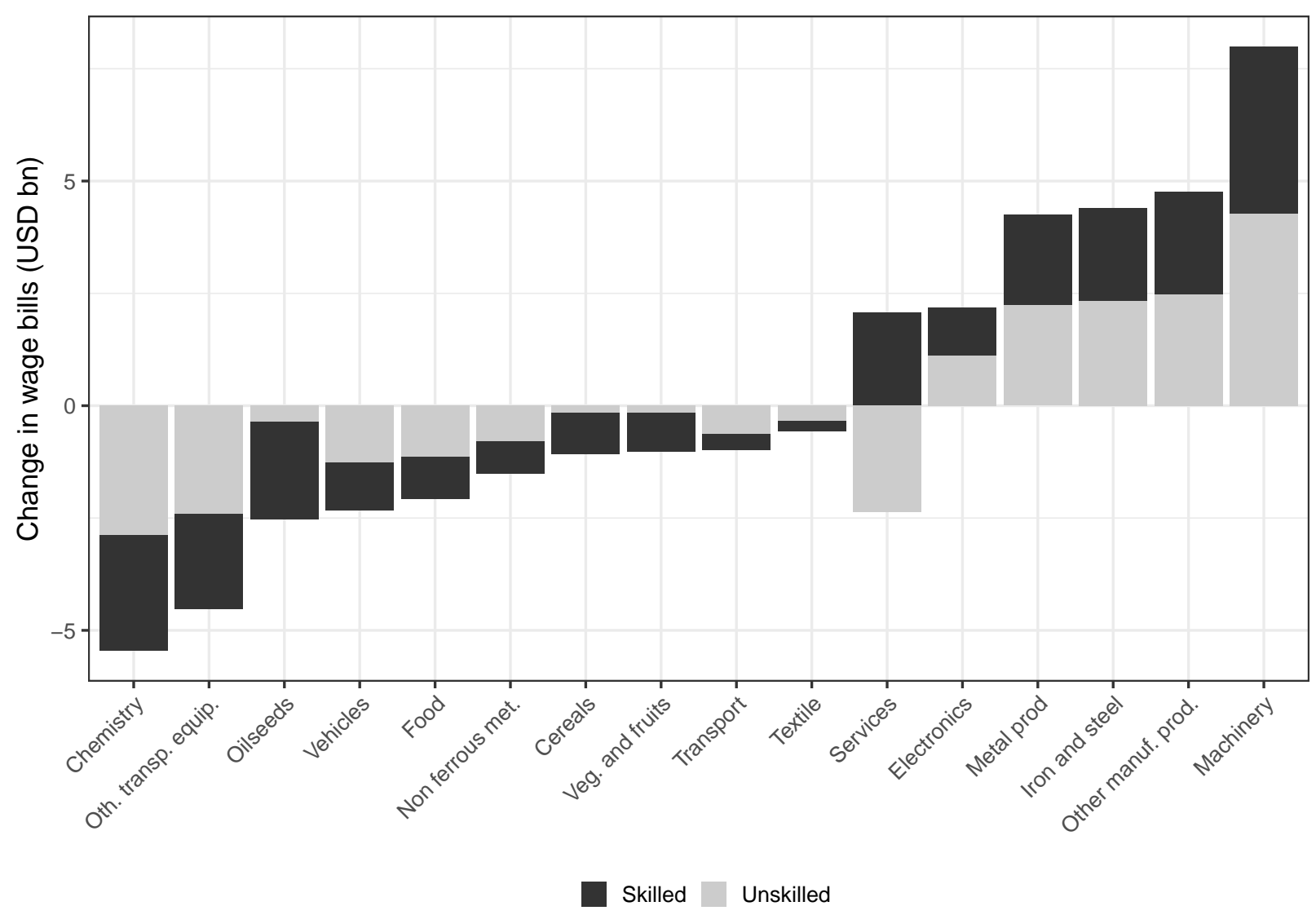

Besides labor, production relies on other factors, and importantly on capital. ${ }^{34}$ We show in figure 6 the total change in US wage bills (i.e. grouping the two categories of workers) and in capital. Differently from the adjustment mechanism pertaining to labor, and provided that the adjustment of the sectoral capital stock is driving the recursive dynamics of the model, ${ }^{35}$ the observed change in capital revenue is the result of net investment in protected sectors and progressive adjustment of the return to capital to its baseline equilibrium value. In the top right quadrant of figure 6 we observe sectors where both components of the value added win: workers and capital owners. These are the protected sectors which did show up in the right quadrants of figure 3). In the bottom left sectors, both factors lose; this is due either to the transmission of prices along the GVCs (Other transport equipment, Vehicles) or to Chinese retaliations (e.g. Oilseeds).

\footnotetext{
${ }^{33}$ For Services, we observe a negative impact on unskilled workers contrasting with the positive impact on skilled workers. However our sectoral detail does not authorize us to decompose this effect.

${ }^{34}$ We do not comment the variation in the return to land for sake of simplicity. It indeed decreases in the relevant sectors.

${ }^{35}$ Sectoral gross investment is driven by the differences in return to capital across sectors, while there is a common depletion rate of installed capital.
} 
Figure 6 - Scenario 1 - Changes in US wage bills and capital revenue, by sector, in 2030 (\%)

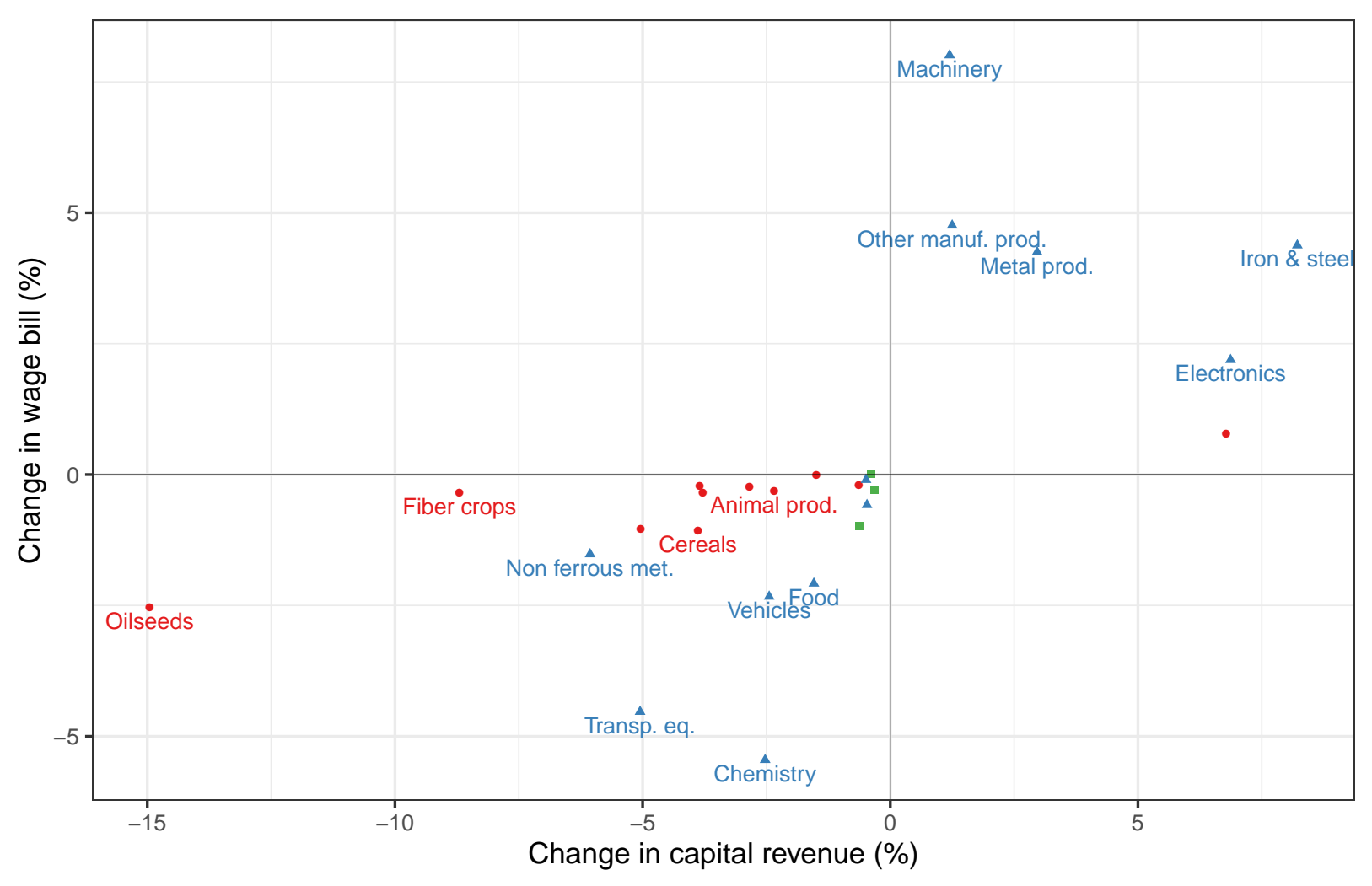

Sector a Primary a Secondary a Tertiary 


\section{Conclusion}

We embedded the most detailed information related to the trade war initiated by the US administration in 2018 and followed by China in a recursive dynamic general equilibrium model of the world economy featuring GVCs and imperfect competition. The channels of transmission of price changes along the value chains were accordingly fully described. Beyond the direct effect of retaliation, tariffs increase the cost of imported intermediate consumption, hence reducing the competitiveness of the imposing country's exports. Tariffs on parts and components also increase the final consumer price of final goods in which they are embodied. Similarly, tariffs on final goods deter export of value added of the domestically produced components contained in these imports.

Our results confirm that the trade war is hitting seriously China; but the US economy is not exempt from adverse consequences. The increase in producer costs detrimental to the competitiveness of US producers translates into losses of market shares on export markets, adding to the toll of retaliation by China and other affected countries.

Ultimately the effects of the trade war on sectoral value added in the US are highly uneven: among industrial sectors, Iron and steel, Electronics, Machinery or Metal products record sizeable gains, while Chemistry, Other transport equipment, Vehicles, Textile or Food record losses. Consistent with political economy determinants, these twists of value added are transmitted to production factors, leading to sizeable creation and destruction of jobs, and reallocation of capital to the benefit of protected sectors, mostly at the expense of their clients.

Entering into a trade war protects certain industries, or retaliates effectively, but this comes at a cost for the entire economy because GVCs are ubiquitous in most of its sectors. The order of magnitude that we obtain, taking stock of general equilibrium effects, is not negligible: $-0.41 \%$ of GDP for the US and $-0.59 \%$ for China. These results confirm the theoretical intuition that trade wars in the presence of GVCs are costly for all belligerents. More generally, this analysis sheds light on the economic consequences of policies disrupting global value chains. 


\section{Bibliography}

Amiti, M., Redding, S. J. and Weinstein, D. E. (2019a), 'The impact of the 2018 tariffs on prices and welfare', Journal of Economic Perspectives 33(4), 187-210.

Amiti, M., Redding, S. and Weinstein, D. (2019b), Who's paying for the U.S. tariffs? A longer-term perspective, Discussion Paper 14229, Centre for Economic Policy Research (CEPR).

Amiti, M., Redding, S. and Weinstein, D. (2020), Who's paying for the US tariffs? A longer-term perspective, Technical report, National Bureau of Economic Research (NBER).

Balistreri, E. J., Böhringer, C. and Rutherford, T. F. (2018), Quantifying disruptive trade policies, Working paper, CESifo.

Bekkers, E. and Teh, R. (2019), Potential economic effects of a global trade conflict: Projecting the mediumrun effects with the wto global trade model, Technical report, WTO Staff Working Paper 2019-04.

Berthou, A., Jardet, C., Siena, D. and Szczerbowicz, U. (2018), 'Quantifying the losses from a global trade war', Banque de France ECO Notepad 19.

BIS (2007), The effect of imports on the national security, Technical report, US Department of Commerce, Bureau of Industry and Security Office of Technology Evaluation.

Blanchard, E., Bown, C. and Chor, D. (2019), Did Trump's trade war impact the 2018 election?, Working Paper 26434, National Bureau of Economic Research.

Blanchard, E. J., Bown, C. P. and Johnson, R. C. (2016), Global supply chains and trade policy, Working Paper 21883, National Bureau of Economic Research.

Bouet, A., Decreux, Y., Fontagné, L., Jean, S. and Laborde, D. (2008), 'Assessing applied protection across the World', Review of International Economics 16(5), 850-863.

Bown, C. P. (2018), 'Trade policy toward supply chains after the great recession', IMF Economic Review 66(3), 602-616.

Bown, C. P., Erbahar, A. and Zanardi, M. (2020), Global value chains and the removal of trade protection, Working paper, Peterson Institute for International Economics.

Caceres, C., Cerdeiro, D. A. and Mano, R. C. (2019), Trade wars and trade deals: estimated effects using a multi-sector model, IMF Working Paper 143, International Monetary Fund.

Caliendo, L. and Parro, F. (2015), 'Estimates of the trade and welfare effects of NAFTA', The Review of Economic Studies 82(1), 1-44.

Cavallo, A., Gopinath, G., Neiman, B. and Tang, J. (2019), Tariff passthrough at the border and at the store: Evidence from us trade policy, Working Paper 26396, National Bureau of Economic Research.

Charbonneau, K. B. and Landry, A. (2018), The trade war in numbers, Technical report, Bank of Canada.

Fajgelbaum, P. D., Goldberg, P. K., Kennedy, P. J. and Khandelwal, A. K. (2020), 'The return to protectionism', The Quarterly Journal of Economics 135(1), 1-55.

Felbermayr, G. and Steininger, M. (2019), 'Trump's trade attack on China - Who laughs last?', CESIFO Policy Brief 3(13).

Fetzer, T. and Schwarz, C. (2019), Tariffs and politics: evidence from Trump's trade wars, Discussion Paper 13579, CEPR.

Fontagné, L., Fouré, J. and Ramos, M. P. (2013), MIRAGE-e: A general equilibrium long-term path of the world economy, Working Paper 2013-39, CEPII.

Fontagné, L., Mitaritonna, C. and Signoret, J. E. (2016), Estimated tariff equivalents of services NTMs, Working Papers 2016-20, CEPII.

Fouré, J., Bénassy-Quéré, A. and Fontagné, L. (2013), 'Modelling the world economy at the 2050 horizon', 
Economics of Transition 21(4), 617-654.

Freund, C., Ferrantino, M., Maliszewska, M. and Ruta, M. (2018), Impacts on global trade and income of current trade disputes, MTI Practice Notes 2, World Bank Group.

Freund, C., Maliszewska, M., Matoo, A. and Ruta, M. (2020), When elephants make peace: The impact of the China-U.S. trade agreement on developing countries, Policy Research Working Paper 9173, The World Bank.

Guimbard, H., Jean, S., Mimouni, M. and Pichot, X. (2012), 'MAcMap-HS6 2007, An exhaustive and consistent measure of applied protection in 2007', International Economics 130, 99-121.

Handley, K., Kamal, F. and Monarch, R. (2019), Rising import tariffs, falling export growth: When modern supply chains meet old-style protectionism, mimeo, Federal Reserve Board.

Hertel, T., Hummels, D., Ivanic, M. and Keeney, R. (2007), 'How confident can we be of CGE-based assessments of free trade agreements?', Economic Modelling 24(4), 611-635.

Kee, H. L., Nicita, A. and Olarreaga, M. (2008), 'Estimating trade restrictiveness indices', The Economic Journal 119(534), 172-199.

Koopman, R. B., Tsigas, M., Riker, D. and Powers, W. (2013), The implications of using value-added trade data for applied trade policy analysis, in D. K. Elms and P. Low, eds, 'Global Value Chains in a Changing World', WTO, chapter 4, pp. 109-134.

Li, M. (2018), CARD trade war tariffs database, Technical report, lowa State University.

Li, M., Balistreri, E., Zhang, W. et al. (2018), The 2018 trade war: Data and nascent general equilibrium analysis, Technical report, Food and Agricultural Policy Research Institute (FAPRI) at lowa State University.

Nicita, A., Olarreaga, M. and Silva, P. (2018), 'Cooperation in WTO's tariff waters?', Journal of Political Economy 126(3), 1302-1338.

Ossa, R. (2014), 'Trade wars and trade talks with data', American Economic Review 104(12), 4104-46.

Vicard, V. (2018), 'Une estimation de l'impact des politiques commerciales sur le pib par les nouveaux modèles quantitatifs de commerce', Focus du CAE 22.

Walmsley, T. and Minor, P. (2016), ImpactECON 002 rev. 2 Supply chain database, data and model documentation, Technical report, ImpactECON.

Waugh, M. E. (2019), The consumption response to trade shocks: Evidence from the US-China trade war, Working Paper 26353, National Bureau of Economic Research. 


\section{Appendix}

\section{A. The long term dynamic baseline}

The macroeconomic baseline of the world economy is constructed with the MaGE model proposed in Fouré et al. (2013). Based on a three-factor (capital, labour, energy) and two-productivity (capital-labour and energyspecific) production function, MaGE is a supply-side oriented macroeconomic growth model, defined at country level for 167 countries. It consists of three steps. First, production factor and productivity data are collected for 1980 to 2010 using World Bank, United Nations and International Labour Organization data. Second, behavioural relations are estimated for factor accumulation and productivity growth, based on these data. Third, these relations are used to project the world economy.

As far as econometric estimations are concerned, one of the original features of MaGE is to estimate TFP (productivity of capital and labor) and energy productivity separately. This is especially important in a model intended for long term projections. Indeed, energy scarcity and subsequent price increases are likely to constitute a major constraint on GDP growth in the future, which can be partially circumvented by progress in energy efficiency. Another interesting feature is to account for the anticipated rise in female participation rates, especially in developing countries, in labor projections. This is based on the estimation of the relation between female participation rates and education. ${ }^{36}$ As far as capital is concerned, its accumulation is modelled assuming imperfect mobility. First savings then their relationship with investment are modelled.

Once these relationships are estimated, the MaGE model takes UN projection of population by age group, ILO male activity rate projections and the projections of oil prices by the Energy International Agency as exogenous variables and projects endogenously the other variables, TFP, energy productivity, female participation rates, savings to investment balances and bilateral real exchange rates. Combining these elements on productivity, labor and capital allows to projet GDP in the long term.

\section{B. Sources for the tariff scenario: US and China tariffs}

\section{B.1. Section 232}

We detail below the sources for the US. ${ }^{37}$ The first lists of aluminum and steel products affected by additional tariffs under section 232 of the US Trade Expansion Act, as well as the magnitude of these tariffs, have been made public on 8 March 2018 by two Presidential proclamations (one for aluminum and one for steel), published in the Federal Register of March 15, 2018. Canada and Mexico were initially exempted. In the following days, negotiations went on; waiting for their final outcome, exemptions were extended to Argentina,

\footnotetext{
${ }^{36}$ Higher education implies lower participation of the youngest females, while making females of other age groups participate more to the labour force.

${ }^{37}$ Official documents of countries other than the US are provided in the Supplementary materials.
} 
Australia, Brazil, the European Union and South Korea, as stated in the Presidential proclamations of March 22, 2018 (published on March 28). At the end of April, two new proclamations updated and detailed these exemptions (proclamations made public on April 30, 2018 and published on the Federal Register on May 5, 2018). In particular, tariffs on imports from Canada, Mexico and the EU finally increased, starting from June 1; Argentina, Brazil and South Korea negotiated voluntary export restrictions (for steel; for aluminum, only Argentina obtained a tariff rate quota, Brazil and South Korea facing increased tariffs), while Australia remained exempted from any trade restriction. ${ }^{38}$

Following the end of the renegotiation of the North American Free Trade Agreement, tariffs imposed by the US to Canada and Mexico (and the resulting retaliatory duties imposed by Canada and Mexico to the US) were removed on May 20, 2019. On the following day, one additional adjustment was made: the additional duties imposed on Turkey were brought back to the level applied to other countries, after they had been increased on August $13,2018 .^{39}$

Below, we give the references of the official documents mentioned above, with which we build the scenarios.

For aluminium:

- March 8, 2018 : https://www.govinfo.gov/content/pkg/FR-2018-03-15/pdf/2018-05477.pdf;

- March 22, 2018 : https://www.govinfo.gov/content/pkg/FR-2018-03-28/pdf/2018-06420.pdf concerning the exemptions;

- April 30, 2018: https://www.govinfo.gov/content/pkg/FR-2018-05-07/pdf/2018-09840.pdf concerning quotas and detailed schedule, when needed;

- May 19, 2019: https://www.govinfo.gov/content/pkg/FR-2019-05-23/pdf/2019-10999.pdf.

For steel:

- March 8, 2018: https://www.govinfo.gov/content/pkg/FR-2018-03-15/pdf/2018-05478.pdf

- March 22, 2018: https://www.govinfo.gov/content/pkg/FR-2018-03-28/pdf/2018-06425.pdf concerning one missing HS6 product category and exemptions;

- April 30, 2018: https://www.govinfo.gov/content/pkg/FR-2018-05-07/pdf/2018-09841.pdf concerning quotas and detailed schedule, when needed;

- May 19, 2019: https://www.govinfo.gov/content/pkg/FR-2019-05-23/pdf/2019-11002.pdf.

\footnotetext{
${ }^{38} \mathrm{An}$ up-to-date timeline is available at https://piie.com/blogs/trade-investment-policy-watch/ trump-trade-war-china-date-guide

${ }^{39}$ https : //www.govinfo.gov/content/pkg/FR-2019-05-21/pdf/2019-10759.pdf
} 


\section{B.2. Section 301}

Additional tariffs taken against China under section 301 of the US Trade Act, and the resulting retaliations from China, went into force in several waves. The US administration first imposed a 25 p.p. additional tariff on around USD 46 billion of imports from China. Tariffs covering around $70 \%$ of these imports went into effect on July 6, 2018 the others on August 23, 2018. ${ }^{40}$.

As China retaliated against these measures with equivalent additional tariffs on similar values of imports from the US, the US imposed additional duties of 10 p.p. on approximately USD 200 billion imports from China that entered into force on September $24,2018 .{ }^{41}$ These duties were initially set to increase to 25 p.p. on March 1, 2019. However, in the first months of 2019, tensions seemed to be contained and the increase was postponed; ${ }^{42}$ the two opponents tried to negotiate a truce, but without success, at least in the first instance. As a result, the increase from 10 to 25 p.p. in US tariffs on the USD 200 bn imports from China took place in May 2019. Again, China retaliated against each move by the US. On September 24, 2018 it increased duties, by 5 to 10 p.p., on around USD 60 bn imports from the US to retaliate against the imposition of additional duties on List 3. On June 1, 2019 China further increased tariffs on a subset, worth USD 35.5 bn, of the USD 60 bn list of September 2018. The resulting additional tariffs were then between 10 to 25 p.p. We also take into account the additional 15\% tariffs imposed on a subset, worth around USD 112 bn of US imports from China, of list 4 entered into force in September 1, 2019 and subsequently halved in February 2020, following the signature of the Phase One Deal. China retaliated to this last wave imposing 5 to $10 \%$ additional tariffs on USD 29 bn of US exports, then halved to 2.5 to $5 \%$ in February 2020.

Below, we give the references of the official documents afore mentioned, with which we build the scenarios. For the US:

- List of products covered by additional duties entered into force on July 6, 2018 (List 1): https://www . govinfo.gov/content/pkg/FR-2018-06-20/pdf/2018-13248.pdf

- List of products covered by additional duties entered into force on August 23, 2018 (List 2): https: //www.govinfo.gov/content/pkg/FR-2018-08-16/pdf/2018-17709.pdf

- List of products covered by additional duties entered into force on September 24, 2018 (List 3): https: //www.govinfo.gov/content/pkg/FR-2018-09-21/pdf/2018-20610.pdf

- Increase in the tariffs applied to List 3 on May 9, 2019: https://www.govinfo.gov/content/pkg/ FR-2019-05-09/pdf/2019-09681.pdf

- List of products covered by additional duties entered into force on September 1, 2019 (List 4A): https://

\footnotetext{
40 These two waves correspond to the "List 1 " and "List 2", as they are called by the US Trade Representative, see https: //ustr.gov/issue-areas/enforcement/section-301-investigations/tariff-actions

41 The products of this wave of tariffs constitute the "List 3 " in the USTR classification.

${ }^{42}$ Federal register freezing the additional duties: https://www.govinfo.gov/content/pkg/FR-2019-03-05/pdf/2019-03935.pdf
} 
ustr.gov/sites/default/files/enforcement/301Investigations/Notice_of_Modification_\%28List_ 4A_and_List_4B\%29.pdf and https://ustr.gov/sites/default/files/enforcement/301Investigations/ Notice_of_Modification $\%$ E2\%80\%93August_2019.pdf

- Decrease in the tariffs applied to List 4A on February 14, 2020: https://ustr.gov/sites/default/ files/enforcement/301Investigations/Notice_of_Modification-January_2020.pdf

For China:

- List of products covered by additional duties entered into force on July 6, 2018: http://gss.mof.gov . cn/zhengwuxinxi/zhengcefabu/201806/P020180616034361843828.pdf

- List of products covered by additional duties entered into force on August 23, 2018: http://gss .mof . gov.cn/zhengwuxinxi/zhengcefabu/201806/P020180616034362364988.pdf

- Lists of products covered by additional duties entered into force on September 24, 2018: http://gss . mof.gov.cn/zhengwuxinxi/zhengcefabu/201808/t20180803_2980950.html

- Lists of products covered by increased additional duties entered into force on June 1, 2019: http://gss . mof.gov.cn/zhengwuxinxi/zhengcefabu/201905/t20190513_3256788.html

- Lists of products covered by additional duties entered into force on Spetember 1, 2019: http://gss . mof . gov.cn/zhengwuxinxi/zhengcefabu/201908/t20190823_3372928.html

- Decrease in the tariffs applied on February 14, 2020: http://gss.mof.gov.cn/gzdt/zhengcefabu/ 202002/t20200206_3466540.htm

\section{Sources for the tariff scenario: countries other than the US and China}

US tariff increases under the Section 232 on aluminium and steel products targeted not only China but all the exporters. As a consequence, several countries retaliated, increasing the tariffs they applied on products they import from the US. Targeted products and the magnitude of the increase vary across retaliating countries. To take this diversity into account, we rely on the following official lists:

- European Union: http://trade.ec.europa.eu/doclib/html/156909.htm.

- Canada:https://www.fin.gc.ca/access/tt-it/cacsap-cmpcaa-1-eng.asp. These measures were cancelled at the end of the renegotiation of the North American Free Trade Agreement, in May 2019.

- Mexico: http://dof .gob.mx/nota_detalle.php?codigo=5525036\&fecha=05/06/2018, cancelled in May 2019.

- India: https://docs.wto.org/dol2fe/Pages/FE_Search/FE_S_S009-DP. aspx?language=E\&CatalogueIdList= 245263 , 245266 , 245272 , 245249 , 245254 , 244331 , 244332 , 244335 , 244292 , 244291\&CurrentCatalogueIdIndex= 4\&FullTextHash=-1264605332\&HasEnglishRecord=True\&HasFrenchRecord=False\&H. These measures 
entered into force several month after their announcement, in June 2019. ${ }^{43}$

- Turkey:https://docs.wto.org/dol2fe/Pages/FE_Search/FE_S_S009-DP.aspx?language=E\&CatalogueIdList= $245263,245266,245272$, 245249 , 245254 , 244331 , 244332 , 244335, 244292 , 244291\&CurrentCatalogueIdIndex= 2\&FullTextHash=-1264605332\&HasEnglishRecord=True\&HasFrenchRecord=False\&H.

- Russia: https://www.alta.ru/tamdoc/18ps0788/.

The European Union also implemented restriction on its import of aluminium and steel products, to avoid diversion effects. This measure is also taken on board, based on the EU Implementing Regulation 2019/159 (https: //eur-lex. europa.eu/legal-content/EN/TXT/HTML/?uri=CELEX : 32019R0159\&qid=1551867756007\&from= EN).

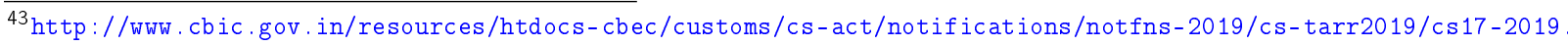
pdf. 


\section{Aggregations}

Table D.1 - Sectoral aggregation

\begin{tabular}{|c|c|c|}
\hline Sector & $\begin{array}{l}\text { Aggregation } \\
\text { label }\end{array}$ & GTAP 9 sector \\
\hline AnimAgri & AnimAgri & ctl, oap, rmk, wol \\
\hline Cereals & Cereals & pdr, wht, gro \\
\hline Chemistry & Chemistry & crp \\
\hline Coal & Coal & coa \\
\hline Elec & Elec & ely \\
\hline Electronic & Electronic & ele \\
\hline FiberCrops & FiberCrops & $\mathrm{pfb}$ \\
\hline Food & Food & $\begin{array}{l}\text { cmt, omt, vol, mil, } \\
\text { pcr, sgr, ofd, b_t }\end{array}$ \\
\hline Gas & Gas & gas, gdt \\
\hline IronSteel & IronSteel & i_s \\
\hline Machinery & Machinery & ome \\
\hline MetalProd & MetalProd & fmp \\
\hline Minerals & Minerals & omn, $\mathrm{nmm}$ \\
\hline NonFer & NonFer & $\mathrm{nfm}$ \\
\hline Oil & Oil & oil \\
\hline Oilseeds & Oilseeds & osd \\
\hline OthCrops & OthCrops & $\mathrm{ocr}$ \\
\hline OtherAgri & OtherAgri & frs, fsh \\
\hline OthManuf & OthManuf & lum, ppp, omf \\
\hline OthTranseq & OthTranseq & otn \\
\hline Petroleum & Petroleum & $\mathrm{p} \_\mathrm{c}$ \\
\hline Serv & Serv & $\begin{array}{l}\text { wtr, cns, trd, cmn, ofi, } \\
\text { isr, obs, ros, osg, dwe }\end{array}$ \\
\hline Sugar & Sugar & $c \_b$ \\
\hline Textile & Textile & tex, wap, lea \\
\hline Transport & Transport & otp, wtp, atp \\
\hline VegFruits & VegFruits & $v \_f$ \\
\hline Vehicles & Vehicles & $\mathrm{mvh}$ \\
\hline
\end{tabular}

Table D.2 - Regional aggregation

\begin{tabular}{|c|c|c|}
\hline Region & $\begin{array}{l}\text { Aggregation } \\
\text { label }\end{array}$ & GTAP 9 region \\
\hline Argentina & Argentina & ARG \\
\hline Australia & Australia & AUS \\
\hline Brazil & Brazil & BRA \\
\hline Canada & Canada & CAN \\
\hline $\begin{array}{l}\text { China and Hong- } \\
\text { Kong }\end{array}$ & ChinaHK & $\mathrm{CHN}, \mathrm{HKG}$ \\
\hline CIS countries & $\mathrm{CIS}$ & $\begin{array}{l}\text { BLR, RUS, UKR, XEE, } \\
\text { KAZ, KGZ, XSU, ARM, } \\
\text { AZE, GEO }\end{array}$ \\
\hline EFTA & EFTA & CHE, NOR, XEF \\
\hline France & France & FRA \\
\hline Germany & Germany & DEU \\
\hline India & India & IND \\
\hline Japan & Japan & JPN \\
\hline Korea & Korea & KOR \\
\hline Latin America & LAC & $\begin{array}{l}\text { BOL, CHL, COL, ECU, } \\
\text { PRY, PER, URY, VEN, } \\
\text { XSM, CRI, GTM, HND, } \\
\text { NIC, PAN, SLV, XCA, } \\
\text { DOM, JAM, PRI, TTO, } \\
\text { XCB }\end{array}$ \\
\hline Mexico & Mexico & MEX \\
\hline Other Oceania & OthOceania & $\mathrm{NZL}, \mathrm{XOC}$ \\
\hline Rest of ASEAN & RoASEAN & $\begin{array}{l}\text { KHM, IDN, LAO, MYS, } \\
\text { PHL, SGP, THA, VNM, } \\
\text { XSE }\end{array}$ \\
\hline Rest of Asia & RoAsia & $\begin{array}{l}\text { MNG, TWN, XEA, BRN, } \\
\text { BGD, NPL, PAK, LKA, } \\
\text { XSA, XTW }\end{array}$ \\
\hline $\begin{array}{l}\text { Rest of European } \\
\text { Union }\end{array}$ & EU26 & $\begin{array}{l}\text { AUT, BEL, CYP, CZE, } \\
\text { DNK, EST, FIN, GRC, } \\
\text { HUN, IRL, ITA, LVA, } \\
\text { LTU, LUX, MLT, NLD, } \\
\text { POL, PRT, SVK, SVN, } \\
\text { ESP, SWE, BGR, HRV, } \\
\text { ROU }\end{array}$ \\
\hline RoW & RoW & $\begin{array}{l}\text { XNA, ALB, XER, BHR, } \\
\text { IRN, ISR, JOR, KWT, } \\
\text { OMN, QAT, SAU, TUR, } \\
\text { ARE, XWS, EGY, MAR, } \\
\text { TUN, XNF, BEN, BFA, } \\
\text { CMR, CIV, GHA, GIN, } \\
\text { NGA, SEN, TGO, XWF, } \\
\text { XCF, XAC, ETH, KEN, } \\
\text { MDG, MWI, MUS, MOZ, } \\
\text { RWA, TZA, UGA, ZMB, } \\
\text { ZWE, XEC, BWA, NAM, } \\
\text { ZAF, XSC }\end{array}$ \\
\hline UK & UK & GBR \\
\hline USA & USA & USA \\
\hline
\end{tabular}


Table E.3 - Scenario 1 - Trade value and protection: most impacted bilateral flows of goods for intermediate consumption

\begin{tabular}{|c|c|c|c|c|c|c|c|}
\hline \multirow[t]{2}{*}{ Sector } & \multirow[t]{2}{*}{ Exporter } & \multirow[t]{2}{*}{ Importer } & \multicolumn{2}{|c|}{ Tariffs (in \%) } & \multirow{2}{*}{$\begin{array}{c}\text { Trade } \\
\text { (USD bn.) }\end{array}$} & \multirow{2}{*}{$\begin{array}{r}\text { Change in prot. } \\
\text { (USD bn.) }\end{array}$} & \multirow[t]{2}{*}{ rev. } \\
\hline & & & Reference & Scenario & & & \\
\hline Machinery & China & USA & 1.6 & 21.5 & 44 & & 8.7 \\
\hline Electronics & China & USA & 0.3 & 19.3 & 25 & & 4.7 \\
\hline Chemistry & China & USA & 2.7 & 20.4 & 24 & & 4.2 \\
\hline Vehicles & China & USA & 1.0 & 23.5 & 14 & & 3.1 \\
\hline Metal prod. & China & USA & 1.8 & 24.4 & 12 & & 2.7 \\
\hline Chemistry & USA & China & 5.1 & 15.2 & 19 & & 1.9 \\
\hline Non ferrous met. & USA & China & 0.7 & 19.7 & 10 & & 1.9 \\
\hline Oilseeds & USA & China & 1.5 & 16.9 & 13 & & 1.9 \\
\hline Iron and steel & EU 27 & USA & 0.2 & 19.8 & 6 & & 1.3 \\
\hline Other manuf. prod. & China & USA & 1.4 & 13.5 & 10 & & 1.2 \\
\hline Machinery & USA & China & 3.8 & 14.8 & 10 & & 1.1 \\
\hline Minerals & China & USA & 3.0 & 20.7 & 6 & & 1.1 \\
\hline Other manuf. prod. & USA & China & 2.0 & 13.3 & 9 & & 1.1 \\
\hline Electronics & USA & China & 0.4 & 7.7 & 14 & & 1.0 \\
\hline Textile & China & USA & 8.1 & 30.2 & 4 & & 0.8 \\
\hline
\end{tabular}

Notes: Sectors are ranked by decreasing impact on tariff revenue.

Source: BACl (2017), MAcMap-HS6, authors' calculation.

\section{E. Additional results}


Table E.4 - Scenario 1 - Trade value and protection: most impacted bilateral flows of goods for final consumption

\begin{tabular}{lllrrrrr}
\hline Sector & Exporter & Importer & \multicolumn{2}{c}{ Tariffs (in \%) } & & Trade & Change in prot. rev. \\
& & & Reference & Scenario & (USD bn.) & (USD bn.) \\
\hline Electronics & China & USA & 0.3 & 10.4 & 142 & 14.4 \\
Machinery & China & USA & 1.4 & 17.6 & 59 & 9.5 \\
Other manuf. prod. & China & USA & 1.6 & 11.9 & 59 & 6.1 \\
Textile & China & USA & 11.8 & 19.7 & 61 & 4.9 \\
Machinery & USA & China & 4.4 & 13.0 & 18 & 1.6 \\
Chemistry & China & USA & 2.9 & 14.3 & 13 & 1.5 \\
Food & China & USA & 5.0 & 25.2 & 5 & 1.1 \\
Food & USA & China & 10.4 & 29.0 & 5 & 1.0 \\
Metal prod. & China & USA & 2.7 & 14.4 & 7 & 0.8 \\
Electronics & USA & China & 2.3 & 11.9 & 6 & 0.6 \\
Transp. eq. & China & USA & 1.5 & 24.6 & 2 & 0.5 \\
Veg. and fruits & USA & China & 6.6 & 30.2 & 2 & 0.5 \\
Transp. eq. & USA & EU 27 & 1.7 & 4.1 & 17 & 0.4 \\
Chemistry & USA & China & 3.8 & 9.2 & 4 & 0.2 \\
Other manuf. prod. & USA & China & 4.8 & 11.4 & 4 & 0.2 \\
Transp. eq. & USA & China & 2.9 & 4.2 & 14 & 0.2 \\
\hline
\end{tabular}

Notes: Sectors are ranked by decreasing impact on tariff revenue.

Source: BACI (2017), MAcMap-HS6, authors' calculation.

Table E.5 - Scenario 1 - Changes in bilateral trade, in the US (variations with respect to the baseline, in 2030)

\begin{tabular}{|c|c|c|c|c|c|c|}
\hline \multirow[t]{2}{*}{ Partner } & \multicolumn{3}{|c|}{ Exports } & \multicolumn{3}{|c|}{ Imports } \\
\hline & $\begin{array}{c}\text { Ref. } \\
\text { (USD bn) }\end{array}$ & $\begin{array}{c}\text { Diff. } \\
\text { (USD bn) }\end{array}$ & $\begin{array}{l}\text { Var. } \\
(\%)\end{array}$ & $\begin{array}{c}\text { Ref. } \\
\text { (USD bn) }\end{array}$ & $\begin{array}{c}\text { Diff. } \\
\text { (USD bn) }\end{array}$ & $\begin{array}{l}\text { Var. } \\
(\%)\end{array}$ \\
\hline Argentina & 14 & -0.5 & -3.5 & 8 & -0.0 & -0.2 \\
\hline Australia & 57 & -3.3 & -5.8 & 20 & 1.4 & 7.2 \\
\hline Brazil & 59 & -2.5 & -4.2 & 40 & 2.0 & 4.9 \\
\hline Canada & 335 & -5.7 & -1.7 & 491 & 24.4 & 5.0 \\
\hline China and Hong-Kong & 355 & -135.9 & -38.2 & 896 & -452.0 & -50.5 \\
\hline $\mathrm{CIS}$ countries & 56 & -3.4 & -6.1 & 94 & -0.2 & -0.2 \\
\hline EFTA & 44 & -2.6 & -6.0 & 48 & 4.1 & 8.6 \\
\hline France & 86 & -5.2 & -6.0 & 69 & 6.4 & 9.3 \\
\hline Germany & 132 & -7.2 & -5.5 & 121 & 12.3 & 10.1 \\
\hline India & 50 & -3.6 & -7.2 & 137 & 9.3 & 6.8 \\
\hline Japan & 145 & -6.0 & -4.2 & 202 & 22.3 & 11.0 \\
\hline Korea & 115 & -4.8 & -4.2 & 109 & 13.4 & 12.3 \\
\hline Latin America & 182 & -5.3 & -2.9 & 201 & 8.7 & 4.3 \\
\hline Mexico & 258 & 0.2 & 0.1 & 354 & 28.8 & 8.1 \\
\hline Other Oceania & 12 & -0.7 & -5.4 & 7 & 0.2 & 3.5 \\
\hline Rest of ASEAN & 154 & -5.0 & -3.2 & 242 & 42.4 & 17.5 \\
\hline Rest of Asia & 83 & -3.4 & -4.0 & 126 & 22.7 & 18.0 \\
\hline Rest of European Union & 320 & -15.6 & -4.9 & 281 & 19.7 & 7.0 \\
\hline RoW & 332 & -13.2 & -4.0 & 414 & 10.6 & 2.6 \\
\hline UK & 150 & -8.4 & -5.6 & 113 & 7.3 & 6.5 \\
\hline
\end{tabular}

Notes: Variations in the policy scenario, in volume, with respect to the reference scenario, based on a Fisher index.

Sources: MIRAGE-e simulations, author's calculation. 
Table E.6 - Scenario 1 - Changes in bilateral trade, in China (variations with respect to the baseline, in 2030)

\begin{tabular}{|c|c|c|c|c|c|c|}
\hline \multirow[t]{2}{*}{ Partner } & \multicolumn{3}{|c|}{ Exports } & \multicolumn{3}{|c|}{ Imports } \\
\hline & $\begin{array}{c}\text { Ref. } \\
\text { (USD bn) }\end{array}$ & $\begin{array}{c}\text { Diff. } \\
\text { (USD bn) }\end{array}$ & $\begin{array}{l}\text { Var. } \\
(\%)\end{array}$ & $\begin{array}{c}\text { Ref. } \\
\text { (USD bn) }\end{array}$ & $\begin{array}{c}\text { Diff. } \\
\text { (USD bn) }\end{array}$ & $\begin{array}{l}\text { Var. } \\
(\%)\end{array}$ \\
\hline Argentina & 20 & 1.5 & 7.4 & 25 & 2.4 & 9.6 \\
\hline Australia & 109 & 4.9 & 4.5 & 211 & -4.0 & -1.9 \\
\hline Brazil & 81 & 5.6 & 6.9 & 128 & 3.0 & 2.4 \\
\hline Canada & 69 & 9.0 & 13.1 & 75 & -3.2 & -4.3 \\
\hline $\mathrm{CIS}$ countries & 400 & 14.4 & 3.6 & 297 & -3.7 & -1.2 \\
\hline EFTA & 38 & 2.7 & 7.2 & 42 & -2.0 & -4.9 \\
\hline France & 115 & 5.9 & 5.1 & 62 & -2.9 & -4.6 \\
\hline Germany & 203 & 9.9 & 4.9 & 123 & -5.9 & -4.8 \\
\hline India & 134 & 8.4 & 6.3 & 118 & -4.9 & -4.1 \\
\hline Japan & 319 & 17.8 & 5.6 & 316 & -16.0 & -5.1 \\
\hline Korea & 240 & 11.6 & 4.8 & 327 & -16.2 & -5.0 \\
\hline Latin America & 134 & 9.5 & 7.0 & 141 & -3.6 & -2.6 \\
\hline Mexico & 70 & 8.6 & 12.2 & 23 & -2.1 & -9.0 \\
\hline Other Oceania & 28 & 1.7 & 6.1 & 38 & -0.5 & -1.3 \\
\hline Rest of ASEAN & 507 & 27.5 & 5.4 & 487 & -13.3 & -2.7 \\
\hline Rest of Asia & 197 & 10.4 & 5.3 & 386 & -21.4 & -5.5 \\
\hline Rest of European Union & 522 & 23.0 & 4.4 & 193 & -8.5 & -4.4 \\
\hline RoW & 592 & 29.6 & 5.0 & 835 & -7.5 & -0.9 \\
\hline UK & 139 & 8.9 & 6.4 & 51 & -2.9 & -5.7 \\
\hline USA & 848 & -427.4 & -50.4 & 391 & -148.9 & -38.1 \\
\hline
\end{tabular}

Notes: Variations in the policy scenario, in volume, with respect to the reference scenario, based on a Fisher index.

Sources: MIRAGE-e simulations, author's calculation. 
Table E.7 - Scenario 1 - Changes in US bilateral trade, by destination use (final vs, intermediate, variations with respect to the baseline, in 2030 )

\begin{tabular}{|c|c|c|c|c|c|c|}
\hline \multirow[t]{2}{*}{ Partner } & \multicolumn{3}{|c|}{ Goods for final consumption } & \multicolumn{3}{|c|}{ Intermediate goods } \\
\hline & $\begin{array}{c}\text { Ref. } \\
\text { (USD bn) }\end{array}$ & $\begin{array}{c}\text { Diff. } \\
\text { (USD bn) }\end{array}$ & $\begin{array}{l}\text { Var. } \\
(\%)\end{array}$ & $\begin{array}{c}\text { Ref. } \\
\text { (USD bn) }\end{array}$ & $\begin{array}{c}\text { Diff. } \\
\text { (USD bn) }\end{array}$ & $\begin{array}{l}\text { Var. } \\
(\%)\end{array}$ \\
\hline \multicolumn{7}{|l|}{ US Exports } \\
\hline Argentina & 4 & -0.2 & -4.7 & 10 & -0.3 & -3.3 \\
\hline Australia & 30 & -1.9 & -6.5 & 27 & -1.7 & -6.2 \\
\hline Brazil & 21 & -1.0 & -4.7 & 37 & -1.6 & -4.2 \\
\hline Canada & 115 & -3.0 & -2.6 & 220 & -4.5 & -2.0 \\
\hline China and Hong-Kong & 90 & -30.4 & -33.8 & 266 & -106.8 & -40.2 \\
\hline $\mathrm{CIS}$ countries & 33 & -2.6 & -7.9 & 24 & -1.3 & -5.4 \\
\hline EFTA & 13 & -0.8 & -6.3 & 31 & -2.0 & -6.7 \\
\hline Rest of European Union & 107 & -1.0 & -0.9 & 213 & 9.8 & 4.6 \\
\hline France & 29 & -0.3 & -0.9 & 57 & 2.8 & 5.0 \\
\hline Germany & 54 & -0.9 & -1.6 & 77 & 3.6 & 4.6 \\
\hline India & 18 & -1.2 & -6.8 & 33 & -2.8 & -8.5 \\
\hline Japan & 44 & -2.3 & -5.2 & 101 & -4.5 & -4.5 \\
\hline Korea & 49 & -2.6 & -5.4 & 66 & -3.0 & -4.5 \\
\hline Latin America & 73 & -3.2 & -4.3 & 109 & -2.9 & -2.7 \\
\hline Mexico & 87 & -0.2 & -0.2 & 171 & -0.6 & -0.3 \\
\hline Other Oceania & 7 & -0.5 & -6.9 & 5 & -0.2 & -4.6 \\
\hline Rest of ASEAN & 56 & -2.7 & -4.9 & 99 & -3.2 & -3.2 \\
\hline Rest of Asia & 28 & -1.7 & -6.0 & 55 & -2.2 & -4.0 \\
\hline RoW & 170 & -8.2 & -4.8 & 162 & -7.0 & -4.3 \\
\hline UK & 62 & -0.4 & -0.6 & 88 & 1.2 & 1.3 \\
\hline \multicolumn{7}{|l|}{ US Imports } \\
\hline Argentina & 2 & 0.1 & 3.3 & 6 & -0.1 & -0.8 \\
\hline Australia & 6 & 0.6 & 9.5 & 13 & 0.9 & 6.5 \\
\hline Brazil & 11 & 1.2 & 10.7 & 29 & 0.8 & 2.7 \\
\hline Canada & 166 & 10.9 & 6.6 & 326 & 13.6 & 4.2 \\
\hline China and Hong-Kong & 511 & -220.9 & -43.2 & 384 & -234.2 & -60.9 \\
\hline CIS countries & 11 & 0.5 & 4.5 & 83 & -0.7 & -0.8 \\
\hline EFTA & 22 & 2.7 & 12.3 & 26 & 1.5 & 5.7 \\
\hline Rest of European Union & 109 & 20.3 & 18.7 & 173 & 25.2 & 14.6 \\
\hline France & 34 & 7.0 & 20.4 & 35 & 4.9 & 14.0 \\
\hline Germany & 58 & 10.2 & 17.5 & 63 & 11.4 & 18.2 \\
\hline India & 50 & 6.0 & 12.1 & 88 & 3.3 & 3.7 \\
\hline Japan & 121 & 14.9 & 12.3 & 81 & 7.9 & 9.7 \\
\hline Korea & 37 & 6.0 & 16.1 & 72 & 7.4 & 10.2 \\
\hline Latin America & 48 & 2.5 & 5.1 & 152 & 6.2 & 4.1 \\
\hline Mexico & 213 & 21.5 & 10.1 & 141 & 7.5 & 5.3 \\
\hline Other Oceania & 3 & 0.1 & 5.6 & 4 & 0.1 & 2.9 \\
\hline Rest of ASEAN & 112 & 15.4 & 13.7 & 130 & 26.6 & 20.5 \\
\hline Rest of Asia & 56 & 9.2 & 16.5 & 71 & 13.6 & 19.3 \\
\hline RoW & 52 & 4.3 & 8.2 & 362 & 7.8 & 2.2 \\
\hline UK & 44 & 4.5 & 10.3 & 69 & 3.4 & 5.0 \\
\hline
\end{tabular}

Notes: Variations in the policy scenario, in volume, with respect to the reference scenario, based on a Fisher index.

Sources: MIRAGE-e simulations, author's calculation. 
Table E.8 - Scenario 1 - Changes in production price and value added, by sector, in Germany

\begin{tabular}{|c|c|c|c|}
\hline \multirow[b]{2}{*}{ Sector } & \multirow{2}{*}{$\begin{array}{c}\text { Prod. price } \\
(\%)\end{array}$} & \multicolumn{2}{|c|}{ Value Added } \\
\hline & & (USD bn) & $(\%)$ \\
\hline Animal prod. & 0.1 & 0.0 & 0.0 \\
\hline Cereals & 0.2 & 0.1 & 0.7 \\
\hline Chemistry & 0.0 & 0.8 & 0.7 \\
\hline Coal & 0.1 & 0.0 & 0.1 \\
\hline Electricity & 0.0 & -0.0 & -0.1 \\
\hline Electronics & 0.0 & 0.1 & 0.7 \\
\hline Fiber crops & -0.0 & -0.0 & -0.5 \\
\hline Food & 0.1 & 0.1 & 0.1 \\
\hline Gas & -0.3 & -0.1 & -0.5 \\
\hline Iron and steel & -0.1 & -0.7 & -4.8 \\
\hline Machinery & 0.0 & 1.0 & 0.4 \\
\hline Metal prod. & 0.0 & 0.1 & 0.1 \\
\hline Minerals & 0.0 & -0.0 & -0.1 \\
\hline Non ferrous met. & 0.1 & 0.0 & 0.4 \\
\hline Oilseeds & 0.0 & -0.0 & -0.2 \\
\hline Other agri. prod. & -0.1 & -0.0 & -0.1 \\
\hline Other crops & 0.1 & 0.0 & 0.3 \\
\hline Other manuf. prod. & 0.1 & -0.3 & -0.3 \\
\hline Petroleum & -0.0 & -0.0 & -0.2 \\
\hline Services & 0.1 & 0.6 & 0.0 \\
\hline Sugar & 0.1 & 0.0 & 0.1 \\
\hline Textile & 0.1 & -0.2 & -1.0 \\
\hline Transp. eq. & 0.0 & 0.2 & 1.2 \\
\hline Transport & 0.0 & -0.9 & -0.6 \\
\hline Veg. and fruits & 0.1 & 0.0 & 0.1 \\
\hline Vehicles & 0.0 & 0.1 & 0.1 \\
\hline
\end{tabular}

Sources: Variations in the policy scenario, in volume, with respect to the reference scenario, based on a Fisher index.

Table E.9 - Scenario 2 - Main aggregate results for selected countries

\begin{tabular}{lrrrrrrr}
\hline & \multicolumn{1}{c}{ USA } & \multicolumn{1}{c}{ China } & Canada & Germany & Japan & Korea & Mexico \\
\hline Total tariff revenue & 130.61 & 9.50 & 6.35 & 7.60 & 21.84 & 1.46 & 11.05 \\
Exports & -10.43 & -4.15 & 3.51 & 0.08 & -4.84 & -0.38 & 4.94 \\
GDP & -0.51 & -0.58 & 0.73 & -0.03 & -0.65 & -0.34 & 0.60 \\
Terms of trade & 0.08 & -1.20 & -0.72 & 0.12 & 0.92 & 0.32 & 0.67 \\
Real return to capital & 0.20 & -0.15 & -0.20 & 0.01 & -0.03 & -0.13 & 0.32 \\
Real return to land & -5.93 & 1.04 & -0.82 & 0.32 & 3.60 & 0.49 & -1.68 \\
Skilled real wages & -0.58 & -1.13 & 0.90 & -0.03 & -0.79 & -0.55 & 0.79 \\
Unskilled real wages & -0.37 & -0.77 & 0.57 & -0.01 & -0.56 & -0.42 & 0.37 \\
\hline
\end{tabular}

Notes: Percentage deviation from the baseline in 2030, in volume. Volumes are based on a Fisher index.

Source: MIRAGE-VA, authors' calculation. 
Table E.10 - Scenario 3 - Main aggregate results for selected countries

\begin{tabular}{lrrrrrrr}
\hline & \multicolumn{1}{c}{ USA } & \multicolumn{1}{c}{ China } & Canada & Germany & Japan & Korea & Mexico \\
\hline Total tariff revenue & 95.38 & 9.29 & 3.52 & -10.71 & 0.56 & -0.02 & 8.69 \\
Exports & -6.51 & -4.25 & 1.21 & 0.62 & 1.06 & -0.03 & 3.37 \\
GDP & -0.39 & -0.60 & 0.29 & 0.07 & 0.12 & -0.04 & 0.36 \\
Terms of trade & 0.34 & -1.21 & -0.02 & 0.07 & 0.03 & 0.28 & 0.93 \\
Real return to capital & 0.20 & -0.13 & -0.23 & -0.02 & -0.01 & -0.01 & 0.17 \\
Real return to land & -5.41 & 1.02 & -0.71 & 0.05 & 0.10 & -0.02 & -1.27 \\
Skilled real wages & -0.40 & -1.15 & 0.50 & 0.14 & 0.12 & 0.01 & 0.46 \\
Unskilled real wages & -0.17 & -0.79 & 0.30 & 0.13 & 0.12 & -0.01 & 0.39 \\
\hline
\end{tabular}

Notes: Percentage deviation from the baseline in 2030, in volume. Volumes are based on a Fisher index.

Source: MIRAGE-VA, authors' calculation.

Table E.11 - Variation in wage bills

\begin{tabular}{|c|c|c|c|c|c|c|c|c|c|}
\hline \multirow[b]{2}{*}{ Sector } & \multicolumn{3}{|c|}{ Scenario 1} & \multicolumn{3}{|c|}{ Scenario 2} & \multicolumn{3}{|c|}{ Scenario 3} \\
\hline & $\begin{array}{c}\text { Skilled } \\
(\%)\end{array}$ & $\begin{array}{c}\text { Unskilled } \\
(\%)\end{array}$ & $\begin{array}{c}\text { Total } \\
\text { (USD bn) }\end{array}$ & $\begin{array}{c}\text { Skilled } \\
(\%)\end{array}$ & $\begin{array}{c}\text { Unskilled } \\
(\%)\end{array}$ & $\begin{array}{c}\text { Total } \\
\text { (USD bn) }\end{array}$ & $\begin{array}{c}\text { Skilled } \\
(\%)\end{array}$ & $\begin{array}{c}\text { Unskilled } \\
(\%)\end{array}$ & $\begin{array}{c}\text { Total } \\
\text { (USD bn) }\end{array}$ \\
\hline Animal prod. & -2.36 & -2.57 & -0.31 & -2.49 & -2.66 & -0.32 & -2.57 & -2.82 & -0.34 \\
\hline Cereals & -3.77 & -3.93 & -1.07 & -4.71 & -4.81 & -1.34 & -3.73 & -3.94 & -1.06 \\
\hline Chemistry & -2.31 & -2.35 & -5.45 & -3.17 & -3.17 & -7.42 & -0.72 & -0.78 & -1.76 \\
\hline Coal & -2.83 & -3.01 & -0.23 & -2.74 & -2.87 & -0.22 & -2.85 & -3.06 & -0.23 \\
\hline Electricity & -0.03 & 0.11 & 0.02 & 0.07 & 0.31 & 0.09 & 0.02 & 0.12 & 0.03 \\
\hline Electronics & 7.50 & 7.55 & 2.19 & 5.89 & 6.01 & 1.73 & 6.72 & 6.66 & 1.95 \\
\hline Fiber crops & -8.41 & -8.49 & -0.35 & -9.58 & -9.61 & -0.39 & -8.88 & -9.01 & -0.36 \\
\hline Food & -1.44 & -1.58 & -2.08 & -1.74 & -1.81 & -2.45 & -1.57 & -1.74 & -2.28 \\
\hline Gas & 7.58 & 8.06 & 0.78 & 7.58 & 8.12 & 0.78 & 7.27 & 7.72 & 0.75 \\
\hline Iron and steel & 9.56 & 9.78 & 4.38 & 14.52 & 14.85 & 6.66 & 7.95 & 8.11 & 3.64 \\
\hline Machinery & 2.06 & 2.13 & 8.01 & 0.85 & 0.95 & 3.45 & 2.07 & 2.10 & 7.96 \\
\hline Metal prod. & 3.76 & 3.80 & 4.25 & 4.87 & 4.96 & 5.52 & 4.03 & 4.02 & 4.52 \\
\hline Minerals & -0.31 & -0.34 & -0.20 & -0.23 & -0.21 & -0.14 & -0.37 & -0.44 & -0.25 \\
\hline Non ferrous met. & -5.79 & -5.81 & -1.52 & -1.92 & -1.70 & -0.47 & -4.58 & -4.60 & -1.20 \\
\hline Oilseeds & -14.69 & -14.77 & -2.53 & -15.16 & -15.19 & -2.61 & -14.92 & -15.04 & -2.57 \\
\hline Other crops & -3.59 & -3.73 & -0.35 & -5.30 & -5.38 & -0.52 & -3.85 & -4.03 & -0.38 \\
\hline Other agri. prod. & -3.85 & -4.05 & -0.21 & -4.06 & -4.18 & -0.22 & -3.92 & -4.16 & -0.21 \\
\hline Other manuf. prod. & 1.71 & 1.67 & 4.76 & 1.72 & 1.73 & 4.87 & 1.51 & 1.44 & 4.15 \\
\hline Transp. eq. & -4.88 & -5.02 & -4.53 & -17.69 & -17.99 & -16.33 & -2.97 & -3.12 & -2.79 \\
\hline Petroleum & -0.14 & -0.05 & -0.10 & -0.09 & 0.07 & -0.01 & 0.25 & 0.31 & 0.31 \\
\hline Services & 0.03 & -0.09 & -0.29 & 0.06 & -0.02 & 3.63 & 0.00 & -0.14 & -3.69 \\
\hline Sugar & -1.35 & -1.53 & -0.01 & -1.57 & -1.70 & -0.01 & -1.48 & -1.69 & -0.01 \\
\hline Textile & -0.55 & -0.77 & -0.58 & 0.29 & 0.10 & 0.16 & -1.22 & -1.48 & -1.18 \\
\hline Transport & -0.31 & -0.36 & -0.98 & -0.16 & -0.14 & -0.43 & -0.37 & -0.51 & -1.32 \\
\hline Veg. and fruits & -5.32 & -5.65 & -1.03 & -5.53 & -5.81 & -1.06 & -5.52 & -5.89 & -1.06 \\
\hline Vehicles & -2.28 & -2.41 & -2.33 & 6.83 & 6.86 & 6.80 & -2.56 & -2.74 & -2.64 \\
\hline
\end{tabular}

Notes: Percentage deviation from the baseline in 2030.

Source: MIRAGE-VA, authors' calculation. 